\title{
Review \\ The Utilization of Algae and Seaweed Biomass for Bioremediation of Heavy Metal-Contaminated Wastewater
}

\author{
Hussein Znad ${ }^{1,2, *}$, Md. Rabiul Awual ${ }^{1}$ and Sri Martini ${ }^{3, *}$ \\ 1 WA School of Mines: Minerals, Energy and Chemical Engineering, Curtin University, GPO Box U1987, \\ Perth, WA 6845, Australia; awual75@yahoo.com \\ 2 School of Engineering, Edith Cowan University (ECU), Perth, WA 6027, Australia \\ 3 Chemical Engineering Department, Universitas Muhammadiyah Palembang, Palembang 30263, Indonesia \\ * Correspondence: h.znad@curtin.edu.au (H.Z.); sri_martini@um-palembang.ac.id (S.M.)
}

Citation: Znad, H.; Awual, M.R.; Martini, S. The Utilization of Algae and Seaweed Biomass for Bioremediation of Heavy MetalContaminated Wastewater. Molecules 2022, 27, 1275. https://doi.org/ $10.3390 /$ molecules 27041275

Academic Editors: Carlo Santoro and Cristina González-Fernandez

Received: 14 January 2022

Accepted: 9 February 2022

Published: 14 February 2022

Publisher's Note: MDPI stays neutral with regard to jurisdictional claims in published maps and institutional affiliations.

Copyright: (C) 2022 by the authors. Licensee MDPI, Basel, Switzerland. This article is an open access article distributed under the terms and conditions of the Creative Commons Attribution (CC BY) license (https:// creativecommons.org/licenses/by/ $4.0 /)$.

\begin{abstract}
The presence of heavy metals in water bodies is linked to the increasing number of industries and populations. This has serious consequences for the quality of human health and the environment. In accordance with this issue, water and wastewater treatment technologies including ion exchange, chemical extraction, and hydrolysis should be conducted as a first water purification stage. However, the sequestration of these toxic substances tends to be expensive, especially for large scale treatment methods that require tedious control and have limited efficiency. Therefore, adsorption methods using adsorbents derived from biomass represent a promising alternative due to their great efficiency and abundance. Algal and seaweed biomass has appeared as a sustainable solution for environmentally friendly adsorbent production. This review further discusses recent developments in the use of algal and seaweed biomass as potential sorbent for heavy metal bioremediation. In addition, relevant aspects like metal toxicity, adsorption mechanism, and parameters affecting the completion of adsorption process are also highlighted. Overall, the critical conclusion drawn is that algae and seaweed biomass can be used to sustainably eliminate heavy metals from wastewater.
\end{abstract}

Keywords: heavy metal; algae; seaweed; wastewater; adsorption; adsorbent

\section{Introduction}

Despite the improvement of the economy and the fulfilment of human needs, industrial development has also caused worrying concerns about the availability of clean water due to wastewater disposal in the environment [1,2]. Some of the most threatening constituents in industrial wastewater are heavy metals due to their high toxicity and low degradability in Nature, resulting in serious health consequences to humans and other living organisms. Therefore, it is essential to purify metal ion-polluted water before its final release back to the environment [2,3]. Industries can generate wastewaters containing high loads of heavy metals [4]. Therefore, particular effort must be taken in terms of heavy metals-contaminated water and wastewater treatment in the first place.

Numerous methods have been applied for metal ion removal from solution such as ion exchange, coagulation/flocculation, flotation, photocatalysis, solvent extraction, electroremediation, biological sludge, adsorption, and membrane technology $[5,6]$. While each method offers both advantages and disadvantages [7], to date, adsorption is still a favored option as it involves a relatively lower energy consumption, easy operation, and high removal efficiency [8]. To support environmental sustainability and circular economy systems, the utilization of low cost biomass sources as adsorbent materials has increased their promising potential $[4,9,10]$. Among other biomaterials, algae and seaweed have been identified as having competitive efficiency for heavy metal elimination from both simulated and raw wastewater [11]. The use of biomass for metals removal offers various benefits such as high metal uptake, good reusability, cost-effectiveness, wide availability in Nature, and the possibility of their usage in both continuous and batch modes [12,13]. 
Algae and seaweed biomass-based adsorbents undergo metal ion transport mediated by energy dispersed through the natural cell membranes enabling their efficient removal [14].

Although some articles have already discussed heavy metal removal by adsorbents derived from low-cost materials, the literature shows that reviews of the current trends in the development of adsorbents made of algae and seaweed for water pollution control regarding metal removal are still rare. Therefore, the importance of this study relates to some points such as the comprehensive critical review regarding the utilization of various types of algae and seaweed as heavy metal adsorbents, and a comparative analysis of their performance along with other substantial relevant aspects such as the toxicity and sources of heavy metals, adsorption mechanisma and factors affecting the adsorption process.

\section{Heavy Metal-Contaminated Water}

Water is the most essential substance for all living creatures and acts as an excellent solvent. The existence of harmful pollutants, including heavy metals, in the water will lead to detrimental alteration of aquatic biotic systems. The main sources of heavy metalcontaminated streams are industrial and agricultural sites, followed by domestic sewage. Other than that, certain natural phenomena like land erosion and volcanic eruptions may also add some unwanted metals to open waters [11]. The stubborn bioaccumulation of heavy metals affecting natural food chains has negative impacts on both human health and the broader ecosystem, especially for direct and long-term exposure.

There are various prominent heavy metal pollutants that need to be seriously managed. To begin with, mercury $(\mathrm{Hg})$ is a highly toxic heavy metal with a damaging level of corrosiveness. Its contamination of water bodies also threatens the industrial sector due to its corrosive impact on machinery containing aluminum [15]. In terms of health measures, long-term exposure to this metal can cause neurological disorders and paralysis. Therefore, setting a tolerable limit is a must. In the European Union (EU) the safe values of mercury in drinking water and wastewater are set at 0.001 and $0.005 \mathrm{mg} / \mathrm{L}$, respectively [16,17].

Lead $(\mathrm{Pb})$ metal ion is a heavy metal mostly found in the wastewater streams produced during battery manufacturing and the piping, ceramic and glass industries. Lead oxidation states, namely $\mathrm{Pb}(\mathrm{IV})$ and $\mathrm{Pb}(\mathrm{II})$, harm human health by triggering damage to the brain, circulatory and nervous systems [18]. Its bioaccumulation in soils can last for for hundreds of years, negatively impacting plant photosynthesis and the food chains in Nature [19]. The World Health Organization (WHO) has set the permissible level of lead in water at $0.05 \mathrm{mg} / \mathrm{L}$ [20].

The impact of arsenic (As) metal exposure in its various oxidation states is also harmful [21,22]. This metal can be generated as a by-product of coal combustion and manufacturing processes. As the exposure to arsenic-contaminated water results in fatal diseases like lung dysfunction and cancer [23], the WHO has set the permissible arsenic limit in drinking water at $0.01 \mathrm{mg} / \mathrm{L}$ [24].

The contamination of copper $(\mathrm{Cu})$ metal is another issue needing considerable attention as its bioaccumulation is detrimental [25]. While limited trace amounts of copper play a valuable role in medicine and the agricultural industries, its exposure beyond the standardized limit can cause liver damage and lung cancer. The maximum permissible level of copper in water was regulated by the United States Environmental Protection Agency (USEPA) at $1.3 \mathrm{mg} / \mathrm{L}$ [26], while other relevant institutions may set different allowable levels.

The existence of carcinogenic cadmium (Cd) metal ion which has high solubility in water merits a serious response [27]. Certain industries like fertilizer production, metal plating, mining, smelting, and fuel combustion form part of its man-made sources. The allowable value of cadmium set by the WHO is around $0.003 \mathrm{mg} / \mathrm{L}$ [28].

The next metal pollutant is chromium (Cr). It can be found in the form of $\mathrm{Cr}(\mathrm{VI})$ or $\mathrm{Cr}(\mathrm{III})$ in industrial waterstreams connected to steel fabrication, the textile and ceramics industries $[5,29]$. For drinking water, the relevant regulatory permissible limit of this metal is below $0.05 \mathrm{mg} / \mathrm{L}$ [8]. 
Trace amounts of nickel (Ni) metal ion in water are also harmful. It can be detected in various waterstreams related to battery, mining, refining, glass and paint manufacturers [30-32]. Cancer-related illnesses can also be triggered by this metal leading to strict regulations on its allowable level in drinking water $(0.015 \mathrm{mg} / \mathrm{L})$ [31].

Finally, zinc $(\mathrm{Zn})$ metal ion is also toxic and easily dissolved in water. It is mainly used in the mining, galvanization, and coal industries [33,34]. Even though certain metals like zinc and copper can be considered essential for biochemical reactions in the human body, excess exposure above the stated thresholds could lead to serious health damage. For this reason, relevant international institutions have given guidance regarding the acceptable values of maximum contaminant levels of heavy metals in water and wastewaters, as summarized in Table $1[4,10,34-36]$.

Table 1. Allowable heavy metal levels in water.

\begin{tabular}{|c|c|c|c|c|}
\hline \multirow{2}{*}{$\begin{array}{l}\text { Heavy } \\
\text { Metals }\end{array}$} & \multicolumn{2}{|c|}{ Allowable Values (mg/L) } & \multirow{2}{*}{ The Industrial Sources of Wastewater } & \multirow{2}{*}{ Effect on Health } \\
\hline & WHO & EPA & & \\
\hline Mercury & 0.01 & 0.05 & Pharmaceutical, paper, pulp, ore, battery & $\begin{array}{l}\text { Neurological diseases, } \\
\text { paralysis, blindness }\end{array}$ \\
\hline Lead & 0.05 & - & Battery, pipe, ceramic, glass production & Brain damage, anaemia, anorexia \\
\hline Arsenic & 0.01 & 0.05 & $\begin{array}{l}\text { Glass, mining, textile, paper, insecticides, } \\
\text { phosphate fertilisers, mining, coal combustion }\end{array}$ & $\begin{array}{l}\text { Lung and kidney cancer, liver } \\
\text { tumour, nausea }\end{array}$ \\
\hline Copper & 1.0 & 0.25 & Fertilizer, paints, pigments, tannery, & $\begin{array}{c}\text { Liver and lung cancer, insomnia, } \\
\text { osteoporosis, heart disease, } \\
\text { headaches, seizures }\end{array}$ \\
\hline Cadmium & 0.003 & 0.005 & $\begin{array}{l}\text { Fertiliser, battery, power plants, mining, } \\
\text { smelting, fuel combustion }\end{array}$ & $\begin{array}{l}\text { lung cancer, kidney failure, } \\
\text { bone lesions }\end{array}$ \\
\hline Chromium & 0.05 & $\begin{array}{l}0.05 \mathrm{Cr}(\mathrm{VI}) \\
0.1 \mathrm{Cr}(\mathrm{III})\end{array}$ & $\begin{array}{l}\text { Synthetic dyes, steel production, textile, } \\
\text { ceramics }\end{array}$ & $\begin{array}{l}\text { Lung cancer, haemorrhage, } \\
\text { vomiting, severe diarrhoea }\end{array}$ \\
\hline Nickel & 0.015 & 0.2 & $\begin{array}{l}\text { Battery, mining, coinage, electroplating, } \\
\text { glass, paints }\end{array}$ & $\begin{array}{l}\text { Lung cancer, dermatitis, } \\
\text { chronic asthma, }\end{array}$ \\
\hline Zinc & 3.0 & 1.0 & $\begin{array}{l}\text { Mining, steel fabrication, galvanisation, } \\
\text { stabilisers, coal combustion }\end{array}$ & $\begin{array}{l}\text { Gastrointestinal disorder, nausea, } \\
\text { lethargy, neurological damage, loss } \\
\text { of appetite }\end{array}$ \\
\hline
\end{tabular}

\section{Technology for Heavy Metal Removal}

\subsection{Electrochemical Methods}

Electrochemistry-related processes for removing metal ions from aqueous media have been considered reliable. The particular mechanism used in this system requires optimizing both anodic and cathodic reactions working in electrochemical cells. The electrical current then is applied as needed for removing metals from water or contaminated solutiona. As a result, the cation will move toward the cathode side, while the anion will be attracted by the anode electrode that could be further flow into a storage tank for subsequent usage. This process is dependable, however, it is relatively costly for large scale industrial application due to the high initial investment cost [37].

\subsection{Biological Method}

Biology-related methods rely on the existence of living microorganisms in the aqueous medium for degrading heavy metals. Even though a longer time is needed to ensure the optimum biological and chemical reactions, and the limited availability of large enough ponds for the process may limit its usage in modern industrial sites, this technique is arguably more environmentally friendly and cost effective [38]. Biological treatment processes can be performed well with the contribution of aerobic, anaerobic, combined aerobic-anaerobic bacteria, fungi or other living microorganisms [39-42]. 


\subsection{Membrane Filtration}

Membrane technology mostly applies pressure-driven systems for treating wastewater using the pressure difference between the two sides of an appropriate mebrane. As a physical barrier, membranes separate the feed into two flowing streams based on some specific selection property. Water and wastewater can pass through membrane pores under pressure affected by particle size, initial concentration of the feed, and operating conditions like temperature, pressure and $\mathrm{pH}$. Membranes, which can be categorized into microfiltration, ultrafiltration, nanofiltration, and reverse osmosis ones by considering their pore size, have attracted increasing interest due to their outstanding pollutant removal efficiency $[3,43,44]$. Other than that, membranes have practical operating procedures, and flexibility in design, however, the initial installation and maintenance cost can be constraints [45]. Another concern when using this technique is its main issue, namely membrane fouling which reduce the performance over time [46].

\subsection{Coagulation and Flocculation}

Coagulation and flocculation work for purifying contaminated water in accordance with the application of flocculant and coagulant agents like aluminum and ferric chloride [47]. In coagulation, the density is increased to destabilize and eliminate the colloidal pollutant particles, leading to further separation of those particles. The next step is the agglomeration of destabilized particles. The flocculation itself may activate heavy metals leading to less removal. Therefore, applying precipitation and spontaneous reduction in the coagulation process can boost metal ion removal. The effectiveness of this process is mostly influenced by the initial pollutant concentration, coagulants and flocculants dosage, and $\mathrm{pH}[47,48]$. Despite the ease of application and good removal efficiency, some side issues including costly chemical reagents and toxic sludge production need further consideration [49].

\subsection{Advanced Oxidation Processes}

Advanced oxidation processes (AOPs) for managing water pollution are able to mineralize organic compounds using hydroxyl radicals [50]. In this category there are some prominent options to perform oxidation processes such as Fenton $\left(\mathrm{H}_{2} \mathrm{O}_{2} / \mathrm{Fe}^{2+}\right)$, Fentonlike $\left(\mathrm{H}_{2} \mathrm{O}_{2} / \mathrm{Fe}^{3+}\right)$, electron beam irradiation, sonolysis, electrochemical oxidation, photoassisted Fenton $\left(\mathrm{H}_{2} \mathrm{O}_{2} / \mathrm{Fe}^{2+} / \mathrm{Fe}^{3+} / \mathrm{UV}\right)$, and photocatalytic reactions [51-54]. Like other procedures, these techniques also have some concerning issues like costly chemicals and the production of toxic sludge and other related by-products [55].

\subsection{Hybrid Methods}

Hybrid treatment methods can provide higher removal efficiency overcoming the drawback of each involved method. An example of this idea can be the membrane case study. When considering how to treat high pollutant-loaded wastewaters using only a membrane filtration system, the main issue is quick and severe fouling of the membrane surface. One possible solution to the issue is a pre-treatment process preceding the membrane treatment plant [56-58]. Different studies have reported a strategy of combining electrocoagulation, membrane, and ozone techniques for treating oily wastewater, resulting in higher COD removal efficiency. In this work, the elimination of targeted pollutants increased nearly 3-fold compared with a single treatment technique [59].

\subsection{Adsorption}

Adsorption processes (Figure 1) are among the most prominent methods for treating contaminated solutions. In terms of metals removal, this method involves the accumulation of metal ions onto adsorbent pores and surfaces forming a layer consisting of metal ions, along with other pollutants $[6,60]$. Adsorption is relatively simple. It has also great removal efficiency, and less energy and chemicals consumption, however, its material preparation and regeneration process should be further concerns [61]. Recently, the uti- 
lization of biomass and other natural materials has been increasing due to their potential, eco-friendliness and cost-effectiveness [4]. Various low-cost material-based adsorbents like clays, zeolites, plants and agricultural wastes as well as animal residues have been reported to be competitive and promising [4,62-65].

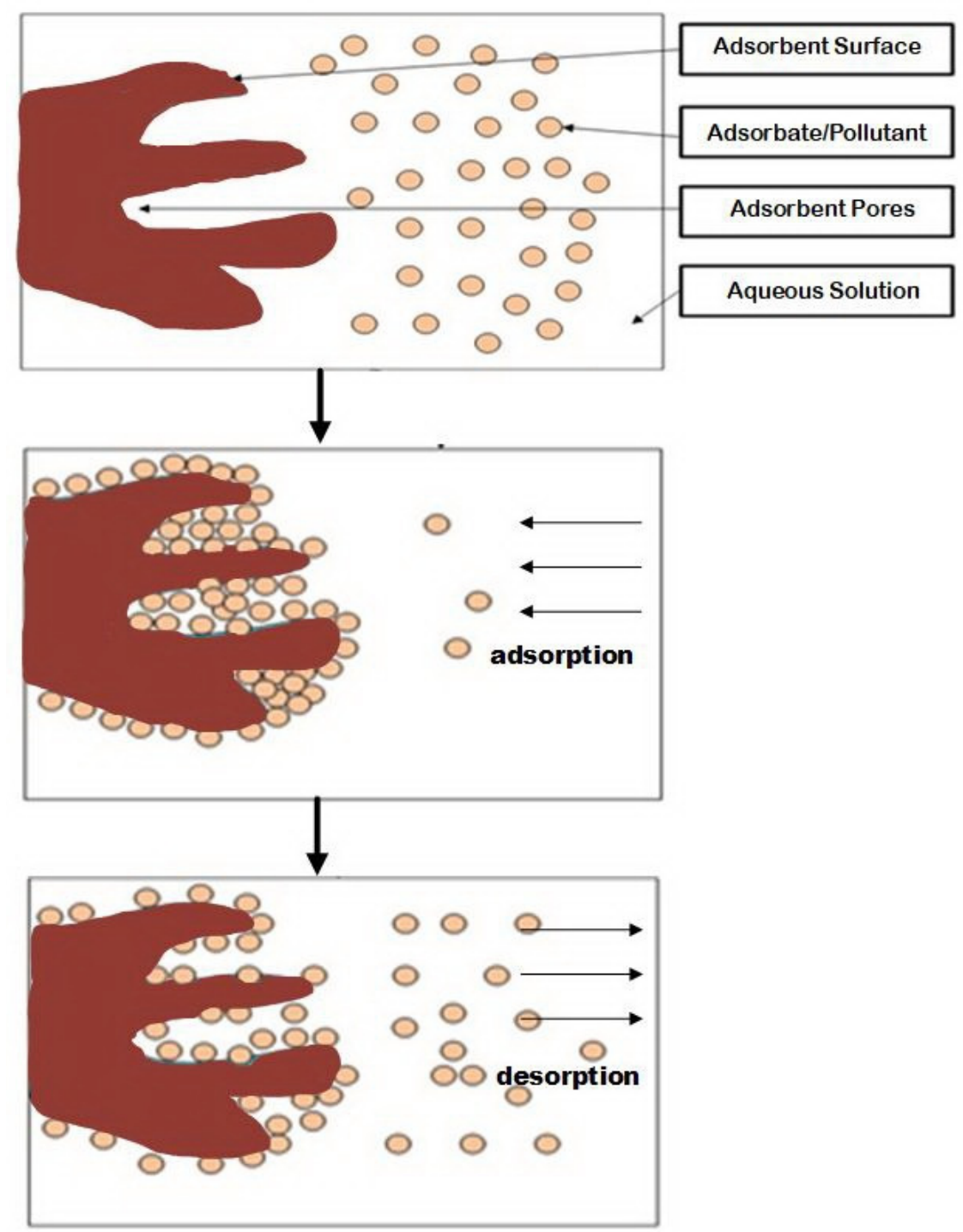

Figure 1. Adsorption and desorption illustration.

\section{The Influencing Parameters of Heavy Metal Adsorption}

The exploration of various natural based-adsorbents has flourished. Bio-adsorbents can experience chemisorption, physisorption, microprecipitation, and oxidation/reduction during the adsorption process [66]. The term chemisorption refers to ion exchange, chelation, and complexation, while physisorption links to electrostatic interactions and van der Waals forces. The adsorbent surface contains functional groups which are crucial for binding metal ions in chemisorption processes. Ion exchange then provides electrostatic interactions between the negatively charged cell walls of the adsorbent and the cations contained in the solution [67]. Furthermore, chelation informs the process of ligand attachment with metal ions forming a ring structure acting as a barrier for the attached minerals to further avoid unwanted chemical reactions [1]. For metal ions, it then connects to the complexation process by forming a complex with the active groups in the cell wall on the cell surface of the adsorbents. The bond formation could be covalent or electrostatic, while the compounds may be neutral, negatively or positively charged [68]. Apart from 
the aforementioned reactions, the following prominent factors have been suggested as significantly influential points for adsorption processes.

\subsection{Initial $p H$}

The initial $\mathrm{pH}$ has an important influence on the ionization of solute metal ions and the surface chemistry of the adsorbent. In this case, it is essential to perform a zeta potential analysis of the adsorbent to determine the charge of the adsorbent surface. Generally, once the $\mathrm{pH}$ solution is lower than the zeta potential, the acidic water will donate more protons than the hydroxide group leading to a positively charged adsorbent surface to better attract the anions. On the contrary, when the surface is negatively charged, it would attract the cation or repel the anion when the $\mathrm{pH}$ is higher than the zeta potential value $[69,70]$.

\subsection{Initial Metal Concentration}

The initial concentration of the metal can be a driving force for mass transfer processes between the solute in solution and the adsorbent. During the initial stage, the plot slope tends to be high, and the removal percentage is at a maximum value due to a higher ratio of the initial molar number of metal ions to the active sites of the adsorbent. When the concentration increases, the ratio and the number of available sites will be lower, resulting in decreased removal efficiency $[4,10]$.

\subsection{Adsorbent Dose}

An optimum adsorption capacity is the result of optimum interactions between the active sites of the adsorbent and dissolved metal ions. Most research has showed that the increase in adsorbent dose would provide more sites for trapping or binding metal ions. In other words, the chance of collisions between adsorbent and metal ions is increased leading to better removal efficiency [71]. Some studies utilizing algae-based adsorbents have also reported the significant influence of adsorbent dose where a higher dose could yield higher metal removal to some extent. However, the optimum dose could reach a certain point in which the adsorbent dose above the optimum point would have less or an insignificant effect on the pollutant removal efficiency $[10,72]$.

\subsection{Contact Time}

Contact time is one of the most influential factors affecting the profile of heavy metal removal as well as economic evaluations. The pattern of contact time analysis mostly shows that there is an increasing removal of heavy metals at the beginning of the process. This is caused by the physical adsorption or ion exchange occurring on the surface of a solid adsorbent. At the beginning stage, there are more free binding sites available before they start to decrease and stagnate due to fewer and fewer empty sites for binding metal ions on the surface [10].

\subsection{Temperature}

The temperature level also has to be taken into account for adsorption processes. An increase in temperature would increase metal ions' tendency to detach from the adsorbent surface. As a result, the functional group bonds would break down, decreasing the forces between metal ions and active sites. In contrast, the higher removal efficiency that occurs at lower temperatures could be attributed to physical adsorption indicating an exothermic mechanism $[73,74]$.

\section{Adsorption Preparation}

Raw biomass should be prepared properly before applying it as an adsorbent. The preparation processes can include physical, thermal, chemical, or combined activation methods. In terms of physical treatment, there are some standard techniques that can be applied such as washing, moderate drying, grinding, or downsizing biomass particles. The range of drying temperature should normally be set below $100^{\circ} \mathrm{C}$ considering the natural 
characteristics of biomass, and this method may not need special techniques like chemical impregnation and magnetization [75]. Therefore, most studies start by synthesizing the bio-adsorbent through some defined physical procedure(s). The next step is thermal or heat treatment. In this case, a high amount of energy is usually needed for activating biomass. Biomass after heat treatment would have a higher surface area and more active sites available on its surface leading to higher adsorption capacity. Generally, pyrolysis processes for biomaterials are conducted at temperatures below $800{ }^{\circ} \mathrm{C}$. This then can be followed by chemical modification to provide more and stronger active sites on the carbonized surface [76]. Chemical treatment that can be implemented as either sole or hybrid activation methods to amplify the affinity of adsorbent to adsorb metal ions through electrostatic interaction correlating to the distribution number of functional groups as well as the surface charge alteration for adsorption improvement [77]. The preparation methods applied for algae and seaweed-based adsorbent are illustrated in Figure 2.

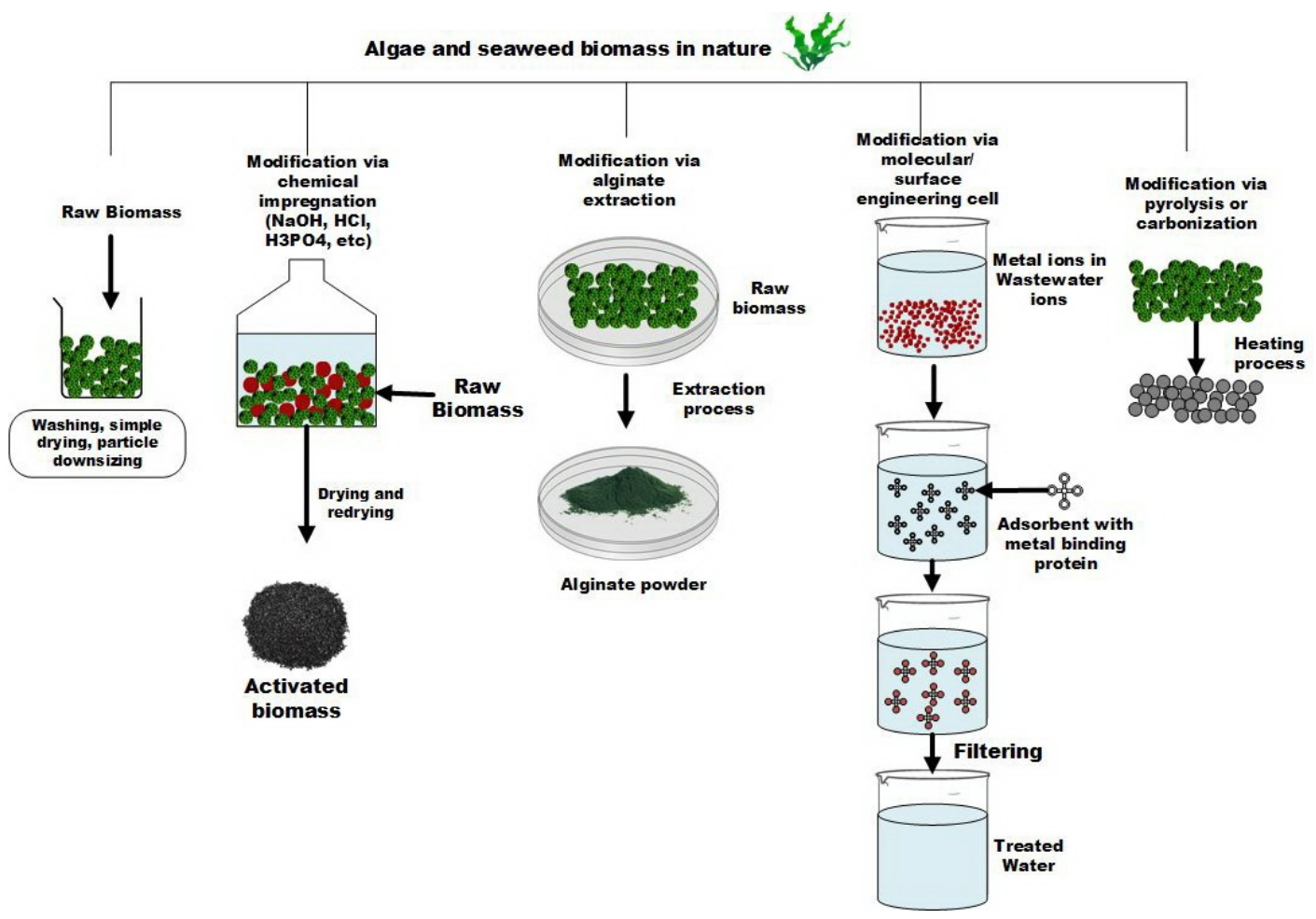

Figure 2. Algae and seaweed-based adsorbent preparation.

\subsection{Adsorption Isotherm and Kinetic Models}

Adsorption process involves the interaction between an adsorbent (a solid phase) and an aqueous medium containing pollutants. This process may occur in a continuous pattern until it reaches the equilibrium state referring to the amount of adsorbed pollutants and the portion remaining in solution at an equilibrium concentration $[10,78]$. The mechanistic models may work based on the adsorption mechanism.

\subsubsection{Adsorption Isotherm}

There are several prominent isotherm models which can be implemented using the experimental data obtained during adsorption processes. They include the Freudlich, Langmuir, Dubinin-Radushkevich, Tempkin, and Elovich isotherm models 


\section{- $\quad$ Freundlich Isotherm Model}

In this model, the site of adsorption is assumed to occur on the heterogeneous surface of the adsorbent with unequal sites and different adsorption energy levels. The formulation of the Freundlich model is expressed by Equation (1) [79,80]:

$$
\ln q_{e}=\ln \mathrm{k}_{\mathrm{f}}+(1) /(\mathrm{n})\left(\ln \mathrm{C}_{\mathrm{e}}\right)
$$

where $q_{e}, \mathrm{C}_{\mathrm{e}}, \mathrm{k}_{\mathrm{f}}$, and $\mathrm{n}$ are the amount of pollutants adsorbed per adsorbent unit at equilibrium $(\mathrm{mg} / \mathrm{g})$, the equilibrium of pollutant concentration in solution $(\mathrm{mg} / \mathrm{L})$, isotherm constant, and the adsorption intensity, respectively [10].

- Langmuir Isotherm Model

This model refers to an ideal homogeneous and uniform surface on an adsorbent for an adsorption process. In other words, all of the sites on the adsorbent surface are assumed equivalent, which can be expressed using Equation (2) [79]:

$$
\mathrm{C}_{\mathrm{e}} / q_{e}=\left(1 /\left(\mathrm{K}_{\mathrm{L}} q_{m}\right)\right)+\mathrm{C}_{\mathrm{e}} / q_{m}
$$

where $q_{m}$ and $\mathrm{K}_{\mathrm{L}}$ are the maximum adsorption capacity $(\mathrm{mg} / \mathrm{g}$ ) and the Langmuir constant, respectively.

- Dubinin-Radushkevich Isotherm Model

This model points to the Gaussian energy distribution on a heterogeneous adsorbent surface, as expressed in the following linearized formula of Equation (3) [81].

$$
\ln q_{e}=\ln q_{m}-\beta \varepsilon^{2}
$$

where $\beta$ and $\varepsilon$ are a constant related to the adsorption energy and the Polanyi potential regarding the equilibrium concentration, respectively. The Polanyi potential can be obtained from the following equation:

$$
\varepsilon=R T \ln \left(1+1 / C_{e}\right)
$$

where $\mathrm{R}$ is the gas constant $(8.314 \mathrm{~J} / \mathrm{mol} \mathrm{K})$, and $\mathrm{T}$ is the absolute temperature $(\mathrm{K})$.

- $\quad$ Tempkin Isotherm Model

The Tempkin model believes in the influence of indirect interactions amongst pollutant particles contained in solution during the adsorption process. In addition, the adsorption heat of all molecules available in the layer would decrease linearly with the increase in surface coverage [79]. The linearized formula of the Tempkin model can be written as follows [82]:

$$
\left.q_{e}=(\mathrm{RTb}) \ln \mathrm{K}_{\mathrm{T}}+(\mathrm{RT} / \mathrm{b}) \ln \mathrm{C}_{\mathrm{e}}\right)
$$

where $\mathrm{b}$ and $\mathrm{K}_{\mathrm{T}}$ are the Tempkin constant linking to the heat of adsorption $(\mathrm{J} / \mathrm{mol})$ and the Tempkin isotherm constant $(\mathrm{L} / \mathrm{g})$, respectively.

\section{- $\quad$ Elovich Isotherm Model}

This model holds the principle of kinetics regarding the number of adsorption sites that escalates exponentially along with the adsorption rate indicating a multilayer adsorption pattern, and it can be stated using the following formula (Equation (6)) [82]:

$$
\ln q_{e} / \mathrm{C}_{\mathrm{e}}=\ln \mathrm{K}_{\mathrm{e}} q_{m}-\left(q_{e} / q_{m}\right)
$$

\subsubsection{Adsorption Kinetic Modelling}

Kinetic studies are important to understand the relationship between the adsorption mechanism and the contact time. This understanding can be diveded into several related models including the pseudo-first order, pseudo-second order, intra-particle diffusion, liquid film diffusion, and double exponential models. As a result, the probability of 
adsorbed pollutant particles and external mass transfer, intra-particle mass transfer, and solute diffusivity can be well understood.

\section{- Pseudo-first and Second Order}

The pseudo-first-order model links to the adsorption sites on the adsorbent surface occupied by pollutant particles in a number proportional to the number of unoccupied sites. The following equation may allow one to reliably measure it (Equation (7)) [79,80,83-85]:

$$
\log \left(q_{e}-q_{t}\right)=\log \left(q_{e}\right)-\left(\mathrm{K}_{1} / 2.303\right) \mathrm{t}
$$

where $q_{t}, \mathrm{~K}_{1}$, and $\mathrm{t}$ are pollutants adsorbed at a specific time $(\mathrm{mg} / \mathrm{g})$, the equilibrium rate constant of pseudo first order adsorption $\left(\mathrm{min}^{-1}\right)$, and time ( $\left.\mathrm{min}\right)$, respectively.

The pseudo-second order model meanwhile can be written as follows [85,86]:

$$
\mathrm{t} / q_{t}=1 /\left(\mathrm{K}_{2} q_{e}^{2}\right)+\left(1 / q_{e}\right) \mathrm{t}
$$

where $\mathrm{K}_{2}$ is the pseudo-second order rate constant $(\mathrm{g} / \mathrm{mg} \mathrm{min})$ estimated by plotting $\mathrm{t} / q_{t}$ vs. $t$. Thus the constant $K_{2}$ can be used to obtain the initial sorption rate (h) at $t=0$ (Equation (9)):

$$
\mathrm{h}=\mathrm{k}_{2} q_{e}^{2}
$$

The values of $\mathrm{k}_{2}, \mathrm{~h}$, and $q_{e}$ can be calculated by the plot of $\mathrm{t} / \mathrm{q}$ vs. $\mathrm{t}$.

- Intra-particle Diffusion

In this adsorption process, pollutant uptake may vary proportionally with $\mathrm{t} 1 / 2$ rather than with contact time, as represented by the following equation [79]:

$$
q_{t}=K_{i d} \mathrm{t}^{(0.5)}
$$

where $K_{i d}$ and $\mathrm{t}^{(0.5)}$ are is the rate constant of intra-particle diffusion $\left(\mathrm{mg} / \mathrm{g} \cdot \mathrm{min}^{0.5}\right)$ and the square root of time (min), respectively. Plotting $q_{t}$ vs. $t^{0.5}$ then indicates a linear relationship, while the value of $K_{i d}$ can be obtained from its slope.

\section{- $\quad$ Liquid Film Diffusion}

The principle of liquid film diffusion relies on the relationship of a liquid and a solid adsorption system in which the rate of accumulated solute in the solid phase of an adsorbent may be equal to that of solute transfer. The following formula then can express this relation Equation (11):

$$
\ln \left(1-q_{t} / q_{e}\right)=-K_{f d} \mathrm{t}
$$

where $\ln \left(1-q_{t} / q_{e}\right)$ and $K_{f d}$ are the fractional attainment of equilibrium and the rate constant of film diffusion, respectively. The plot of $\ln \left(1-q_{t} / q_{e}\right)$ vs. $t$ confirms a linear relationship. Additionally, the value of $K_{f d}$ comes from the slope of the plot.

\section{Algae or Seaweed-Based Bio-Adsorbents for Sequestering Heavy Metals}

Both raw and modified adsorbents derived from algae and seaweed biomass have been reported. Some of the research is summarized in Table 2. In recent years, the efforts to produce novel algae- and seaweed-based adsorbents using extraction, nanoparticles, molecular and chemical modes have achieved remarkable improvements regarding the metal binding capacity and the elucidation of inherent adsorption mechanisms (Figure 2) [87]. Furthermore, heavy metal removal using biomaterials is also influenced by the porosity level and presence of functional groups such as amine, carbonyl, hydroxyl, thiol, carboxyl, and other natural compounds that supporting metal binding like lignins, cellulose, lipids, hydrocarbons, proteins, and tannins. The adsorption capacity and adsorption speed are also affected closely by the exchange capacity of surface cation along with the aforementioned particular operating conditions. 
Table 2. The usage of algae/seaweed-based adsorbents for heavy metals removal.

\begin{tabular}{|c|c|c|c|c|c|}
\hline Metal Ions & Adsorbent Material & Preparation/Activation Technique & $\begin{array}{l}\text { Removal Efficiency } \\
\text { (\%)/Adsorption } \\
\text { Capacity (mg/g) }\end{array}$ & $\begin{array}{l}\text { Optimum Operating } \\
\text { Conditions }\end{array}$ & Refs. \\
\hline \multirow[b]{2}{*}{ Lead } & $\begin{array}{l}\text { Seaweed Turbinaria } \\
\text { ornata }\end{array}$ & $\begin{array}{l}\text { Washing, drying }\left(80^{\circ} \mathrm{C}, 6 \mathrm{~h}\right) \text {, grinding } \\
(1-1.5 \mathrm{~mm})\end{array}$ & $99.80 \%$ & $\begin{array}{l}\text { Metal concentration } 99.8 \mathrm{mg} / \mathrm{L}, \\
\text { agitation speed } 250 \mathrm{rpm} \text {, and } \\
\text { adsorbent dose } 16.2 \mathrm{~g} / \mathrm{L}\end{array}$ & [88] \\
\hline & $\begin{array}{l}\text { Marine alga Gelidium } \\
\text { amansii }\end{array}$ & $\begin{array}{l}\text { Washing, drying }\left(70^{\circ} \mathrm{C}, 72 \mathrm{~h}\right) \text {, grinding } \\
(125 \mu \mathrm{m}) \text {, mixing with distilled water, } \\
\text { incubating and stirring (room temperature, } \\
30 \mathrm{~min}) \text {, and final drying }\left(70^{\circ} \mathrm{C}, 72 \mathrm{~h}\right)\end{array}$ & $100 \%$ & $\begin{array}{l}\text { Metal concentration } 200 \mathrm{mg} / \mathrm{L}, \\
\text { temperature } 45^{\circ} \mathrm{C}, \mathrm{pH} 4.5, \\
\text { adsorbent dose } 1 \mathrm{~g} / \mathrm{L} \text {, contact } \\
\text { time } 60 \text { min at static condition }\end{array}$ & [89] \\
\hline \multirow[t]{2}{*}{ Chromium } & $\begin{array}{c}\text { Brown alga } \\
\text { (Cystoseira barbata and } \\
\text { Cystoseira crinite) }\end{array}$ & $\begin{array}{l}\text { Washing, drying (sunlight and oven }(24 \mathrm{~h} \text {, } \\
\left.60^{\circ} \mathrm{C}\right) \text {, powdering }(100-800 \mu \mathrm{m})\end{array}$ & $\begin{array}{c}\mathrm{Cr}(\mathrm{III}): \\
70.70 \% \text { (C. barbata), } 73.34 \% \\
\text { (C. crinite) } \\
\text { Cr (VI): } \\
35 \% \text { (C. barbata), } 28 \%(\mathrm{C} . \\
\text { crinite) }\end{array}$ & $\begin{array}{l}\mathrm{Cr}(\mathrm{III}): \\
\text { Metal concentration } 100 \mathrm{ppm} \text {, } \\
\text { contact time } 120 \mathrm{~min}, \mathrm{pH} 4.5 \text {, } \\
\text { adsorbent dose } 0.1 \mathrm{~g} / 50 \mathrm{~mL} \text {. } \\
\text { Cr(VI): } \\
\text { Metal concentration } 100 \mathrm{ppm} \text {, } \\
\text { contact time } 24 \mathrm{~h} \text {, adsorbent } \\
\text { dose } 100 \mathrm{mg} / 50 \mathrm{~mL} \text {, pH } 2.0)\end{array}$ & {$[90]$} \\
\hline & $\begin{array}{c}\text { Brown algae Sargassum } \\
\text { dentifolium }\end{array}$ & $\begin{array}{c}\text { Washing, drying }\left(50^{\circ} \mathrm{C}, 24 \mathrm{~h}\right) \text {, grinding } \\
(0.3868 \mu \mathrm{m})\end{array}$ & $\begin{array}{l}\mathrm{Cr}(\mathrm{VI}) \\
99.68 \%\end{array}$ & $\begin{array}{l}\text { Adsorbent dose } 1.5 \mathrm{~g} / \\
100 / \mathrm{mL} \text {, metal concentration } \\
100 \mathrm{ppm} \text {, contact time } \\
\text { flocculation state } 1 \mathrm{~h} \text { followed } \\
\text { by } 12 \mathrm{~h} \text { static, } \mathrm{pH} 7.0 \text {, } \\
\text { temperature } 50^{\circ} \mathrm{C} \text {. }\end{array}$ & [91] \\
\hline \multirow[b]{2}{*}{ Nickel } & $\begin{array}{l}\text { seaweed Sargassum } \\
\text { filipendula }\end{array}$ & $\begin{array}{c}\text { Washing, drying }\left(60^{\circ} \mathrm{C}, 24 \mathrm{~h}\right) \text {, grinding } \\
(0.737 \mathrm{~mm}) \text {, extraction using formaldehyde } \\
\text { and hydrochloric acid solutions, } \\
\text { precipitation, redrying }\left(60^{\circ} \mathrm{C}, 24 \mathrm{~h}\right)\end{array}$ & $45 \%$ & $\begin{array}{l}\text { Flow rate (dynamic system) } \\
0.5 \mathrm{~mL} / \mathrm{min}, \mathrm{metal} \\
\text { concentration } 1.0 \mathrm{mmol} / \mathrm{L} \\
\text { Temperature } 25^{\circ} \mathrm{C}\end{array}$ & [92] \\
\hline & Algae biomass & $\begin{array}{c}\text { Microalgae cultivation in batch mode with } \\
\text { the help of Basal medium containing } \\
\text { chemicals such as } \mathrm{KNO}_{3} \\
\mathrm{Na}_{2} \mathrm{HPO}_{4} \cdot 12 \mathrm{H}_{2} \mathrm{O}, \mathrm{MgSO}_{4} \cdot 7 \mathrm{H}_{2} \mathrm{O} \\
\mathrm{FeSO}_{4} \cdot 7 \mathrm{H}_{2} \mathrm{O} \text {, and } \mathrm{CaCl}_{2} \cdot 2 \mathrm{H}_{2} \mathrm{O} \text {, for } \\
\text { creating a revolving algal biofilm. } \\
\text { maintaining the culture in which half of } \\
\text { the culture medium being exchanged with } \\
\text { new medium each week for more than } \\
\text { four years }\end{array}$ & $95 \%$ & $\begin{array}{l}\text { Metal concentration } 100 \mathrm{mg} / \mathrm{L} \text {, } \\
\text { pH } 7\end{array}$ & [93] \\
\hline \multirow[b]{2}{*}{ Cobalt } & $\begin{array}{c}\text { Red alage } \\
\text { Gracilariacorticata }\end{array}$ & $\begin{array}{l}\text { Washing, drying, grinding, sieving }(53 \mu \mathrm{m}, \\
75 \mu \mathrm{m}, 105 \mu \mathrm{m}, 125 \mu \mathrm{m} \text { and } 152 \mu \mathrm{m})\end{array}$ & $87.80 \%$ & $\begin{array}{l}\text { Metal concentration } 50 \mathrm{mg} / \mathrm{L} \text {, } \\
\text { pH 5, adsorbent dose } 104 \mathrm{~g} / \mathrm{L}, \\
\text { temperature } 303 \mathrm{~K} \text { or } 29.85^{\circ} \mathrm{C}\end{array}$ & [94] \\
\hline & Algae Hypnea Valentiae & $\begin{array}{c}\text { Raw adsorbent: } \\
\text { Washing, crushing, sieving }(0.5-1 \mathrm{~mm}) \text {, } \\
\text { rewashing, drying }\left(80^{\circ} \mathrm{C}, 24 \mathrm{~h}\right) \text {. } \\
\text { Modified adsorbent: } \\
\text { All the above procedures followed by } \\
\text { chemical impregnation }(10 \% \text { of } \\
\text { formaldehyde, } 1 \mathrm{~h} \text {, room temperature, } \\
\text { gentle mixing), filtering, rewashing, } \\
\left.\text { redrying (overnight, } 60^{\circ} \mathrm{C}\right)\end{array}$ & $\begin{array}{c}\text { Raw adsorbent } \\
10.98 \mathrm{mg} / \mathrm{g} \\
\text { Modified } \\
\text { adsorbent } 16.66 \mathrm{mg} / \mathrm{g}\end{array}$ & $\begin{array}{l}\text { Metal concentration } 0.7 \mathrm{mg} / \mathrm{L} \\
\text { temperature } 30^{\circ} \mathrm{C}, \mathrm{pH} 6, \\
\text { adsorbent dose } 2 \mathrm{~g} / \mathrm{L}\end{array}$ & [95] \\
\hline Cadmi-um & $\begin{array}{l}\text { Brown seaweed } \\
\text { Sargassum filipendula }\end{array}$ & $\begin{array}{l}\text { Washing, drying }\left(60^{\circ} \mathrm{C}, 24 \mathrm{~h}\right) \text {, milling, } \\
\text { sieving }(<1 \mathrm{~mm}) \text {. Alginate extraction using } \\
\text { formaldehyde solution }(0.4 \% \mathrm{w} / \mathrm{w}, 30 \mathrm{~min}) \text {, } \\
\text { rinsing, mixing with } \mathrm{HCl} \text { solution } \\
(0.1 \mathrm{moL} / \mathrm{L}, 2 \mathrm{~h}) \text {, followed by mixing with } \\
\text { sodium carbonate solution }(2 \% \mathrm{w} / \mathrm{v}, 5 \mathrm{~h}, \\
\left.60^{\circ} \mathrm{C}\right) \text {. Filtration to separate residue and } \\
\text { the liquid phase with the solubilized } \\
\text { alginate. Final washing with deionised } \\
\text { water. Ethanol }(1: 1 \mathrm{v} / \mathrm{v}) \text { for the alginate } \\
\text { precipitation. Drying the residue and } \\
\text { precipitated alginate }\left(60^{\circ} \mathrm{C}, 24 \mathrm{~h}\right), \text { milling } \\
\text { and sieving }(0.737 \mathrm{~mm})\end{array}$ & $0.43 \mathrm{mmol} / \mathrm{g}$ & $\begin{array}{l}\text { Metal concentration } 2 \mathrm{mmol} / \mathrm{L} \text {, } \\
\text { temperature } 303 \mathrm{~K}, \mathrm{pH} 3.5\end{array}$ & [96] \\
\hline Arsenic & $\begin{array}{l}\text { Brown seaweed } \\
\text { Sargassum muticum }\end{array}$ & $\begin{array}{l}\text { Washing, drying }\left(60^{\circ} \mathrm{C}\right) \text {, grinding }(5 \text { and } \\
12 \mathrm{~mm}) \text { rewashing, redrying in overn } \\
\left(60^{\circ} \mathrm{C}\right), \text { mixing with } 0.1 \mathrm{~mol} / \mathrm{L} \text { of } \mathrm{FeCl}_{3} \\
0.1 \mathrm{~mol} \mathrm{~L}{ }^{-1} \text { solution, stirring }(200 \mathrm{rpm}) \text {, } \\
\text { precipitation using } \mathrm{NaOH} 10 \mathrm{~mol} / \mathrm{L} \text { for } \\
24 \mathrm{~h} \text {, filtration (pore size } 2 \mathrm{~mm}) \text {, rewashing, } \\
\text { redrying }\left(60^{\circ} \mathrm{C}\right)\end{array}$ & $\approx 100 \%$ & $\begin{array}{l}\text { Metal concentration } 2.5 \mathrm{mg} / \mathrm{L} \text {, } \\
\text { pH 7, temperature } 293 \mathrm{~K}\end{array}$ & [97] \\
\hline Mercury & $\begin{array}{c}\text { Macroalgae } \\
\text { Ulva intestinalis, } \\
\text { Ulva lactuca, } \\
\text { Fucus spiralis, } \\
\text { Fucus vesiculosus, } \\
\text { Gracilaria sp., } \\
\text { Osmundea pinnatifida. }\end{array}$ & $\begin{array}{c}\text { Washing (tap water and synthetic } \\
\text { seawater), maintaining macroalgae in } \\
\text { aquarium with aerated seawater (a week, } \\
\text { natural light approximately } 12 \mathrm{~L}: 12 \mathrm{D} \text {, room } \\
\text { temperature } 22 \pm 2^{\circ} \mathrm{C} \text { ), separation, } \\
\text { freeze-drying }\end{array}$ & $\begin{array}{l}95 \% \\
90 \% \\
85 \% \\
80 \% \\
90 \% \\
80 \%\end{array}$ & $\begin{array}{l}\text { Metal concentration } \\
1 \mathrm{~mol} / \mathrm{dm}^{3} \text {, contact time } 72 \mathrm{~h} \text {, } \\
\text { room temperature, } \mathrm{pH} 8.5\end{array}$ & [98] \\
\hline
\end{tabular}


Table 2. Cont.

\begin{tabular}{|c|c|c|c|c|c|}
\hline Metal Ions & Adsorbent Material & Preparation/Activation Technique & $\begin{array}{l}\text { Removal Efficiency } \\
\text { (\%)/Adsorption } \\
\text { Capacity (mg/g) }\end{array}$ & $\begin{array}{c}\text { Optimum Operating } \\
\text { Conditions }\end{array}$ & Refs. \\
\hline \multirow{2}{*}{ Zinc } & $\begin{array}{l}\text { Green seaweed } \\
\text { Ulva lactuca }\end{array}$ & $\begin{array}{l}\text { Washing, drying in an oven }\left(24 \mathrm{~h} \text { at } 60^{\circ} \mathrm{C}\right) \text {, } \\
\text { crushing for smaller particle size } \\
(0.7-1 \mathrm{~mm})\end{array}$ & $128 \mathrm{mg} / \mathrm{g}$ & $\begin{array}{c}\text { Adsorbent dose } 0.2 \mathrm{~g} / 100 \mathrm{~mL} \text {, } \\
\text { contact time } 6 \mathrm{~h} \text {, agitation } \\
150 \mathrm{rpm}, \text { temperature } 31 \pm \\
1^{\circ} \mathrm{C}, \mathrm{pH} 4.5\end{array}$ & [99] \\
\hline & $\begin{array}{l}\text { Green macro algae } \\
\text { Caulerpa scalpelliformis }\end{array}$ & $\begin{array}{c}\text { Washing, drying under sun light }(24 \mathrm{~h}) \text {, } \\
\text { drying in an oven }\left(50^{\circ} \mathrm{C}, 48 \mathrm{~h}\right), \text { particle } \\
\text { downsizing measured by zetasizer } \\
(1326 \mathrm{~nm})\end{array}$ & $83.3 \mathrm{mg} / \mathrm{g}$ & $\begin{array}{c}\text { Adsorbent dose } 1.5 \mathrm{~g} / \mathrm{L}, \\
\text { contact time } 1 \mathrm{~h} \text {, agitation } \\
150 \mathrm{rpm} \text {, temperature } 30^{\circ} \mathrm{C} \text {, } \\
\text { pH } 5.7\end{array}$ & [100] \\
\hline \multirow[b]{2}{*}{ Multi-metals } & $\begin{array}{c}\text { Brown algae } \\
\text { Sargassum polycystum }\end{array}$ & $\begin{array}{l}\text { Washing, drying under }(24 \mathrm{~h}), \text { multiple } \\
\text { drying in an oven }(24 \mathrm{~h})\left(50^{\circ} \mathrm{C}, 12 \mathrm{~h}\right), \\
\text { grinding, sieving }(496.5 \mathrm{~nm})\end{array}$ & $\begin{array}{l}\text { Cadmium: } 86.20 \\
\text { Zinc: } 92.90 \% \text {, }\end{array}$ & $\begin{array}{c}\text { Cadmium: } \\
\text { pH: 4.65, adsorbent dose } \\
\text { 1.8 g/L, agitation speed } 76 \mathrm{rpm} \\
\text { Zinc: } \\
\text { pH 5.7, adsorbent dose } 1.2 \mathrm{~g} / \mathrm{L}, \\
\text { agitation speed } 125 \mathrm{rpm}\end{array}$ & [101] \\
\hline & $\begin{array}{l}\text { Seaweed Sargassum } \\
\text { filipendula }\end{array}$ & $\begin{array}{l}\text { Washing, drying in an oven }\left(60^{\circ} \mathrm{C}, 24 \mathrm{~h}\right) \text {, } \\
\text { sieving to obtain the medium particle } \\
\text { diameter } 0.737 \mathrm{~mm} \text {. } \\
\text { Extraction procedure: mixing biomass } \\
\text { with formaldehyde solution }(0.4 \% \mathrm{v} / \mathrm{v}, \\
30 \mathrm{~min}) \text {, and washing, and mixing with } \\
\text { hydrochloric acid solution }(0.1 \mathrm{~mol} / \mathrm{L}, 2 \mathrm{~h}) \text {, } \\
\text { contacting to carbonate solution }(2 \% \mathrm{w} / \mathrm{v} \text {, } \\
\left.60^{\circ} \mathrm{C}, 5 \mathrm{~h}\right) \text {. Alginate separation by vacuum } \\
\text { filtration } \\
\text { and ethanol for precipitation }(1: 1 \mathrm{v} / \mathrm{v}) \text {, } \\
\text { further drying and sieving }\end{array}$ & $\begin{array}{c}\text { Chromium } 0.864 \mathrm{~mol} / \mathrm{g} \\
\text { Zinc } \\
0.302 \mathrm{mmol} / \mathrm{g} \\
\mathrm{Nickel} \\
0.347 \mathrm{mmol} / \mathrm{g}\end{array}$ & $\begin{array}{l}\text { Temperature } 50^{\circ} \mathrm{C} \text {, total metal } \\
\text { concentration } 1 \mathrm{mmol} / \mathrm{L} \\
(17.33 \mathrm{mg} / \mathrm{L} \text { of } \mathrm{Cr} ; 19.56 \mathrm{mg} / \mathrm{L} \\
\text { of } \mathrm{Ni} \text {; and } 21.79 \mathrm{mg} / \mathrm{L} \text { of } \mathrm{Zn})\end{array}$ & [102] \\
\hline
\end{tabular}

\subsection{Lead Metal Ions}

To begin with, a study has analyzed the feasibility of using algae biomass from the species Turbinaria ornata for adsorbing lead from metal-contaminated solutions [88]. After massive washing, the marine algae was dried at $80^{\circ} \mathrm{C}$ for $6 \mathrm{~h}$, and then powdered for actual usage. In this work, acidic conditions were found to be effective to remove the targeted metal and the initial metal concentration, adsorbent dose, and the speed of agitation were identified as important factors for success. Under optimum operating conditions, around $99.80 \%$ of the lead present could be removed. This happened at an initial concentration of lead of $99.80 \mathrm{mg} / \mathrm{L}$, an agitation speed of $250 \mathrm{rpm}$ and an adsorbent dose of $16.20 \mathrm{~g} / \mathrm{L}$. A decreasing lead adsorption trend at higher doses has been noted, confirming the theoretical analysis. In this case, an adsorbent dose beyond the threshold would result in decreasing accumulation of pollutants trapped on the adsorbent active sites.

As the species of the biomass may have various particular properties, another study then investigated another algae species, namely Gelidium amansii, as adsorbent by implementing the two-level Plackett-Burman factorial design [89]. After simple preparation steps like washing, drying at $70{ }^{\circ} \mathrm{C}$ for around three days, and a downsizing process until the biomass particles had the average size of $125 \mu \mathrm{m}$, the prepared adsorbent was applied for adsorbing lead ions from solution. It was then confirmed that the operating parameters like solution $\mathrm{pH}$, metal concentration, and temperature mainly controlled the performance of the adsorbent during the adsorption process. An acidic medium ( $\mathrm{pH} 4.5$ ) was also found optimum for adsorbing lead metal where complete removal could be achieved at an initial lead and adsorbent concentration, temperature, and contact time by $200 \mathrm{mg} / \mathrm{L}, 1 \mathrm{~g} / \mathrm{L}$, $45^{\circ} \mathrm{C}$, and $60 \mathrm{~min}$, respectively. The study utilized functional groups analysis which confirmed the existence of phosphate, carbonyl, phenolic, and methylene groups as important contributors to the excellent adsorption outcome.

\subsection{Chromium Metal Ions}

Chromium is among the heavy metals of concern and hence the subject of serious investigations. Some studies have reported their findings using biomass-based adsorbents. The brown algae known as Cystoseira barbata and Cystoseira crinite, for example, was concluded to be dependable chromium adsorbents [90]. In the study, both $\mathrm{Cr}$ (III) and $\mathrm{Cr}$ (VI) could be significantly eliminated from wastewater solutions. Parameters like $\mathrm{pH}$ and 
contact time were identified as the main indicators for adsorption analysis. Firstly, the algal biomass was cleaned several times using distilled water before double drying using natural sunlight and a laboratory oven for around $24 \mathrm{~h}$ at $60{ }^{\circ} \mathrm{C}$. The homogenization of biomass particle size was conducted within the range of 100 and $800 \mu \mathrm{m}$. Proper contact with wastewater solution containing chromium metal ion was carried out after chemical modification using $\mathrm{CaCl}_{2}$ and acetone. The aim of this chemical procedure was to eliminate any proteins and lipids in the hope of increasing the active sites on the adsorbent surface. This study reported that no retention occurred for $\mathrm{Cr}(\mathrm{VI})$ ions at an acidic $\mathrm{pH}$ of 4.5. Interestingly, while no retention happened for $\mathrm{Cr}(\mathrm{III})$ metal ions at an extremely acidic $\mathrm{pH}$ of 2.0, that $\mathrm{pH}$ value provided the maximum adsorption of $\mathrm{s} \mathrm{Cr}(\mathrm{VI})$ ion. To conclude, $\mathrm{Cr}(\mathrm{VI})$ ion could be eliminated from an aquatic environment using these typical algae species. The proton form obtained by harnessing the reducing features of $\mathrm{Cr}(\mathrm{VI})$ via electron transfer occurred better in acidic condition for electron donor groups. Around $45 \%$ of the $\mathrm{Cr}(\mathrm{VI})$ with an initial metal concentration of 100 ppm then could be retained.

Husein then led a study group to continue the exploration of another algae type, namely Sargassum dentifolium, for eliminating $\mathrm{Cr}(\mathrm{VI})$ metal ions from synthetic wastewater solution [91]. Common preparation treatments like washing, drying in an oven at $50{ }^{\circ} \mathrm{C}$, and size reduction were also applied followed by characterization on specific surface area of adsorbent using Brunauer-Emmett Teller (BET) method according to nitrogen adsorption and desorption isotherms. By applying a factor at a time experiments, the efficiency of $\mathrm{Cr}(\mathrm{VI})$ removal could be determined towards the low and high level of each factor. The optimum conditions were recapitulated using a full factorial experimental design. Ultimately, this work claimed the potential of the adsorbent used by informing that around $99.68 \%$ of the targeted metal could be adsorbed at an adsorbent dose $1.50 \mathrm{~g}$, particle size $0.3868 \mu \mathrm{m}$, and initial metal concentration of $100 \mathrm{ppm}$. In addition, its reusability was also found promising, as almost $65 \%$ of the adsorbed metal could be removed in the first cycle, while the relative stability of regeneration was determined to be good within the first three cycles of the adsorption and desorption process.

\subsection{Nickel Metal Ions}

As one of prominent metal ions detected in various industrial wastewaters, it is worth investigating the potential of biomass-based adsorbents for removing nickel metal from water bodies. A study responded to this idea by utilizing the seaweed species named Sargassum filipendula as a nickel adsorbent [92]. Using a dynamic fixed bed system for the adsorption process, an evaluation of flow rates and feed concentrations was performed. Nickel-contaminated solution with an initial concentration of $1.0 \mathrm{mmol} / \mathrm{L}$ was flowed at various rates $(0.50,0.80$, and $1.0 \mathrm{~mL} / \mathrm{min})$ at room temperature to the bottom of the designated column. Initial treatment on the biomass was started by repetitive washing. It was then dried at $60{ }^{\circ} \mathrm{C}$ for a day and ground to achieve a particle diameter of around $0.737 \mathrm{~mm}$. Prior to contact with nickel contaminated solution, an alginate extraction procedure was conducted on the powdered biomass with the help of two chemical solutions, namely formaldehyde and hydrochloric acid, followed by rewashing using deionized water. Based on the experiments, around $45 \%$ of the nickel content could be removed at a flow rate and initial metal concentration of $0.5 \mathrm{~mL} / \mathrm{min}$ and $1.0 \mathrm{mmol} / \mathrm{L}$, respectively. Additionally, regeneration measurements confirmed that even the residue of this activated adsorbent could be reused to remove nickel from solution to some extent even though the regeneration assessment led to the conclusion that the column did not perform further adsorption stages after the second desorption step.

Another work then tried to develop an algal biofilm reactor for removing nickel ions from industrial effluents that have high nickel loadings of up to $5000 \mathrm{mg} / \mathrm{L}$ [93]. The microalgae culture was taken care of along with the half of the culture medium being periodically swapped for new Bold's Basal Medium. The medium consisted of several chemical compounds such as $\mathrm{KNO}_{3}, \mathrm{Na}_{2} \mathrm{HPO}_{4} \cdot 12 \mathrm{H}_{2} \mathrm{O}, \mathrm{MgSO}_{4} \cdot 7 \mathrm{H}_{2} \mathrm{O}$ and $\mathrm{FeSO}_{4} \cdot 7 \mathrm{H}_{2} \mathrm{O}$. The batch mode reactor had a liquid reservoir which was replaced with $\mathrm{Ni}$-contaminated 
wastewater. The experimental data analysis showed that this algae biofilm reactor system could decrease nickel concentrations in solution by more than $90 \%$ yielding a nickel removal rate of $534 \mathrm{mg} / \mathrm{L}$-day. Therefore, it can be concluded that indigenous microalgae grown using this mechanism could purify industrial wastewaters having high loadings of nickel ions.

\subsection{Cobalt Metal Ions}

Water and wastewater containing toxic cobalt ions has to be purified before releasing it to the environment. Bioadsorption can be a great reliable options for this purpose. To overcome the challenges, the potential of a red algae with the species name Gracilaria corticata was investigated by Raju et al. [94]. In their work, several relevant parameters were selected and varied, including contact time, initial $\mathrm{pH}$, cobalt ion concentration, adsorbent particle size and dose as well as temperature. Before usage, this red algae was repetitively cleaned and naturally dried under solar light. In order to create a higher adsorbent surface, the particle size of the dried material was further reduced to powder form with various sizes $(53,75,105,125$ and $152 \mu \mathrm{m})$. The equilibrium agitation time needed for adsorbing cobalt ions was $60 \mathrm{~min}$, while the optimum $\mathrm{pH}$ was determined to be $\mathrm{pH} 5$, at which up to $87.8 \%$ of nickel removal efficiency was achieved. In addition, when the adsorbent dose and temperature by $30 \mathrm{~g} / \mathrm{L}$ and $303 \mathrm{~K}$, respectively, reported as optimum condition, modelling measurements suggested that the maximum cobalt removal efficiency could be $96.57 \%$, which would happen at $\mathrm{pH} 4.87$, adsorbent dose $31.79 \mathrm{~g} / \mathrm{L}$, and initial cobalt concentration $19.77 \mathrm{mg} / \mathrm{L}$. This result was improved when temperature was also increased as indicated by thermodynamic analysis.

A study led by Vafajoo confirmed the significant removal of cobalt (II) metal ions from solution by either raw or modified Hypnea valentiae, a species of algae [95]. While raw adsorbent was used directly after standard washing and particle size reduction, the modified version was further treated chemically using a formaldehyde solution. This batch scale investigation mainly focused on the effect of adsorbent dose, metal concentration in solution, and contact time on the adsorbent performance. A maximum adsorption capacity of $10.98 \mathrm{mg} / \mathrm{g}$ and $16.66 \mathrm{mg} / \mathrm{g}$ for raw and modified algae, respectively, can be achieved under the optimum conditions (temperature $30^{\circ} \mathrm{C}$, initial cobalt concentration of $0.7 \mathrm{mg} / \mathrm{L}, \mathrm{pH} 6$ and sorbent dose $2 \mathrm{~g} / \mathrm{L}$ ). In accordance with isotherm analysis, the Langmuir mechanism was believed to be the dominant model during adsorption, while its kinetics followed a pseudo second order model. Apart from that, a study on biomass regeneration indicated a promising reusability rate as the adsorbent could still perform relatively stable even after three adsorption cycles with a maximum capacity of adsorbent regeneration of $66 \%$. For this purpose, the saturated adsorbent was cleaned using $0.1 \mathrm{M}$ of $\mathrm{HCl}$ acting as desorbing chemical agent.

\subsection{Cadmium Metal Ions}

For cadmium metal, the potency of algae biomass as an alternative adsorbent has also been documented. To begin with, the algal species Ulva fasciata and Ulva lactuca were proven promising to reduce the concentration of $\mathrm{Cd}(\mathrm{II})$ in solution, even under various culture atmospheres [103]. Despite their simple preparation steps like washing, drying, and grinding, the adsorbents could reach maximum adsorption capacities of 8.353 and $8.804 \mathrm{mg} / \mathrm{g}$ for Ulva fasciata and Ulva lactuca, respectively. Characterization analysis via Fourier transform infrared spectroscopy showed the presence of prominent functional groups such as alkali hydroxyl, amide hydrogen bonda, and carbonyl groups. benefitting the binding force of the adsorbent active sites.

Other work then conducted an evaluation on the extraction of alginate residue of the brown seaweed Sargassum filipendula for adsorbing cadmium metal ions [96]. After standard cleaning and powdering procedures, the raw biomass was activated via chemical impregnation using formaldehyde and hydrochloric solution in sequential order. The extraction process was carried out with the help of sodium carbonate solution. In short, 
laboratory tests showed a satisfactory outcome where up to 0.394 and $0.429 \mathrm{mmol} / \mathrm{g}$ of targeted adsorbate could be adsorbed at optimum temperatures of 293 and 303 K, respectively. In terms of the thermodynamic and kinetic examination, it was found that this adsorption run in a spontaneous and exothermic mode fitted to an external film model regarding mass transfer. In this case, the values of the kinetic constant were found to be $0.129,0.064$ and $0.066 \mathrm{~min}^{-1}$ at the initial concentrations of $1.0,1.5$ and $2.0 \mathrm{mmol} / \mathrm{L}$, respectively, obeying Freundlich and the Dubinin-Radushkevich models.

\subsection{Arsenic Metal Ions}

Arsenic has long been identified as an extremely harmful toxicant. It can easily to pollute open waters due to either natural phenomena or man-made activities like mining and agricultural industries. While more complex technology can be implemented for its elimination from a watery environment, the use of bio-adsorbents could be a green solution for treating arsenic-contaminated water and wastewater. A study group became interested in examining a brown seaweed, namely Sargassum muticum, to solve the issue [97]. In order to enhance the ability of raw biomass to bind the targeted metal, the biomass was further washed and converted to iron-coated seaweed using $\mathrm{FeCl}_{3}$ solution. In depth analysis of the experimental data of the corresponding equilibrium and kinetic study regarding As (III) and As (V) suggested that maximum adsorptions of $4.2 \mathrm{mg} / \mathrm{g}$ and $7.3 \mathrm{mg} / \mathrm{g}$ could be obtained at $\mathrm{pH} 7$ and $20{ }^{\circ} \mathrm{C}$ temperature, respectively. The uptake of As(III) tended to increase with the increase in $\mathrm{pH}$. In contrast, the iron leaching went down when the $\mathrm{pH}$ increased due to the increasing solubility rate of iron hydroxide in the acidic environment. Moreover, As(III) adsorption underwent a redox reaction triggered by the involvement of As(III) oxidation to form As(V) along with the change of Fe(III) to Fe(II) when arsenate was the targeted adsorbate.

\subsection{Mercury Metal Ions}

Exposure to mercury even at trace amounts can have a huge detrimental effect on human health. This concern has encouraged some studies to further develop algae-based adsorbents for binding mercury ions. The removal of this metal using various microalgae species has given much information related to the potential of biomass. To start with, Fabre et al., selected six species of algae namely Ulva intestinalis, Ulva lactuca, Fucus spiralis, Fucus vesiculosus, Gracilaria sp., and Osmundea pinnatifida as mercury adsorbents [98]. The washed algae biomasses were tested on a bench scale. It was found that the mercury adsorption mechanism followed the metabolically active adsorption process regarding metal incorporation onto the adsorbent surface. By obtaining an average metal removal efficiency of more than $80 \%$, this study confirmed the competitive values of algae-based adsorbents. Bearing in mind that these adsorbents were used in their raw versions with no extensive modification, this indicates their beneficial characteristics as adsorbents.

Regarding the capability of being an alternative sorbent material, it is interesting to explore the diversity of algae and seaweed species. Therefore, a study simultaneously assessed three other species of algae having different natural colours, namely Ulva lactuca (green), Gracilaria gracilis (red) and Fucus vesiculosus (brown), for their mercury uptake [104]. This study used these abundantly available biomasses in the marine environment for targeting mercury ions dissolved in solution as concentrations that were set within the range of 10-100 $\mu \mathrm{g} / \mathrm{L}$. A comprehensive analysis then disclosed that all selected biomasses could perform well, achieving adsorption capacities of more than $209 \mu \mathrm{g} / \mathrm{g}$. Specifically, the comparative analysis of metal accumulation in living and dried biomass indicated that the green Ulva lactuca outperformed the red and brown algae. This conclusion referred to higher efficiency rate achieved at a faster contact time with more than $99 \%$ metal elimination using $500 \mathrm{mg} / \mathrm{L}$ of adsorbent dose. As a result, the treated water could meet the allowable standard of mercury content in drinking water. 


\subsection{Zinc Metal Ions}

Despite its harmful effect, the heavy metal zinc also acts as a useful mineral at extremely low concentrations. Its solubility in water may lead to easy dispersion in wastewater streams derived from industrial sectors including mining and coal manufacturer. In relation to water pollution control, the presence of zinc can be managed well by adsorption technology, especially by using bio-adsorbents made of ubiquitous biomass like the marine seaweed Ulva lactuca, which has been proven effective for zinc removal from solution [99]. Senthilkumar and team used raw wastewater derived from phosphating industry as the aqueous medium for this purpose. Batch scale work via the adsorption technique was set up. With a maximum particle size by $1 \mathrm{~mm}$, the cleaned dried biomass was contacted with the medium for the arranged time. Experimental analysis pointed out that nearly acid medium of $\mathrm{pH} 4.5$ was the optimum condition allowing the adsorbent to bind more metal ions with a maximum adsorption capacity of $128 \mathrm{mg} / \mathrm{g}$. In addition, $\mathrm{HCl}$ solution was found to perform remarkably well for regenerating the used adsorbent whereby around $99.6 \%$ of the adsorbed metal could be released from the surface and pores of the sorbent despite experiencing a $25 \%$ mass loss. This indicator is promising for further adsorbent usage in larger industrial wastewater treatment plants.

The appealing outcome of the previous work then increased the interest in conducting investigations on other algae for fabricating low-cost adsorbents. Jayakumar led a study to examine the adsorptive feasibility of the algae Caulerpa scalpelliformis that can be easily found in seawater environments [100]. After intensive washing, drying, and downsizing processes, a certain amount of nanometre-sized adsorbent was contacted thoroughly with a zinc polluted solution for about $60 \mathrm{~min}$ at a temperature of $30{ }^{\circ} \mathrm{C}$. Primary parameters for the experimental work determined by implementing a Box-Behnken design gave pH 5.7, adsorbent dose of $1.5 \mathrm{~g} / \mathrm{L}$ and a stirring speed of $150 \mathrm{rpm}$ as the optimum variables. Therewith, by obeying Langmuir isotherm model, the metal uptake could reach $83.30 \mathrm{mg} / \mathrm{g}$, while the kinetic analysis indicated that the result was better explained by a pseudosecond order model. From the perspective of the thermodynamic study, the adsorption process indicated a spontaneous and endothermic mechanism. The recyclable nature of the adsorbent was also reliable, as it had a relatively stable performance even after multiple adsorption cycles.

\subsection{Multi-Metals Removal}

Real industrial wastewaters mostly contain more than one heavy metal. The presence of multiple metals in raw wastewater is believed to strongly influence the accuracy of specific ion uptake by an adsorbent. Apart from that aspect, there are also various factors such as the level of nutrients, biomass growth, and the illumination rate that mostly affect metal adsorption processes in Nature. In order to understand the bio-adsorption process regarding multiple metals content, some investigations have been carried out using controlled working conditions. The potential of a brown algae, namely Sargassum polycystum, for the simultaneous adsorption of both cadmium and zinc ions was examined [101]. After massive washing to remove any impurities, the synthesized biomass particles were ground to an average size of $496.5 \mathrm{~nm}$. Sample solutions were prepared by dissolving both $\mathrm{Cd}\left(\mathrm{NO}_{3}\right)_{2} .4 \mathrm{H}_{2} \mathrm{O}$ and $\mathrm{ZnSO}$. Ultimately, a Box-Behnken design (BBD) was applied to predict the optimum conditions for metals removal and indicated that the optimum values of $\mathrm{pH}$, adsorbent dose, and agitation speed for cadmium and zinc were 4.65, $1.8 \mathrm{~g} / \mathrm{L}$, and $76 \mathrm{rpm}$, and at 5.7,1.2 g/L and $125 \mathrm{rpm}$, respectively. Furthermore, the metals uptake at equilibrium was inclined to better fit a Langmuir isotherm model meaning that both cadmium and zinc mostly adopted a single layer mechanism. By following a pseudo-second order model along with spontaneous and endothermic mode of thermodynamic inclination, the maximum adsorption capacities of cadmium and zinc were found to be $105.26 \mathrm{mg} / \mathrm{g}$ and $116.2 \mathrm{mg} / \mathrm{g}$, respectively.

Another group reported the adsorption behavior for the elimination of multiple metal ions dissolved in water [102]. With the specification of alginate extraction residue in the 
preparation stage, the algal species named Sargassum filipendula was engaged for simultaneous removal of three prominent metal ions mostly detected in industrial wastewater like chromium, nickel, and zinc. After a standard preparation procedure, the adsorbent was further ground to obtain an average particle size diameter of $0.737 \mathrm{~mm}$. The extraction was done by employing chemicals like formaldehyde, hydrochloric acid and sodium carbonate solutions in consecutive order to achieve more active sites on the adsorbent surface. This work used both simulated and raw effluents generated by tannery and leather manufacturers along with the entry and outlet sites of an urban water treatment plant. The initial characterization of collected raw industrial wastewaters denoted the existence of other metal ions such as magnesium, aluminum, iron, and lead at various concentration levels even though some metal elements were found to be lower than the standard detection limit. Batch experiments were carried out without $\mathrm{pH}$ adjustment. Overall, there was a higher affinity tendency for chromium metal in synthetic solution under the controlled conditions. In the supervised scenario, chromium achieved around 85\% uptake, while zinc and nickel reached less than $40 \%$ removal with respect to the increase in temperature as a positive driver for adsorption at equilibrium. In contrast, the percentage of chromium elimination was significantly lower in the selected raw wastewaters. This can be linked to the higher competitiveness amongst the ions to occupy the binding sites on the adsorbent surface along with the presence of detected and undetected pollutants. Specifically, wastewater collected from an urban water station entry, for example, showed 80\%, 70\%, and 55\% of removal efficiency for zinc, nickel, and chromium, respectively. A different outcome was noticed for wastewater derived from the outlet of the urban water treatment facility which just indicated around $42 \%$ and $5 \%$ of zinc and chromium removal, respectively, with no nickel removal detected. Furthermore, while tannery effluent only showed zinc and chromium removal by around $40 \%$ and $25 \%$, respectively, leather wastewater showed a removal percentage of the three metals by $70 \%, 5 \%$, and $22 \%$ for zinc, nickel, and chromium, respectively.

\section{Regeneration and Disposal of Saturated Bio-Adsorbents}

The literature shows that various attempts have been widely applied for regeneration of saturated or used adsorbents, including algal and seaweed-based adsorbents. Efforts were conducted in order to improve the lifespan of adsorbents by a recycling process via chemical activation after the first adsorption enabling the usage of cleaned adsorbent for further adsorption cycles. In this case, desorbing agents have been used to regenerate those saturated adsorbents. Some studies refer to alkalis as effective desorbing agents for desorbing heavy metals from chemically modified adsorbents, while acids are favorable for desorption processes of bio-adsorbent, especially, chelating the agent, ethylenediamine tetraacetic acid (EDTA). The ability of each biomass-based adsorbent to perform well in an adsorption process would reduce the time after several adsorption cycles until it reaches irreversible point. Once a saturated bio-adsorbent has worked unreliably for further usage due to an extreme decrease in its adsorption capacity, it then should be disposed of and managed properly based on the regulations established by relevant parties and labelled as hazardous waste [105].

\section{Conclusions}

It has been foreseen that the increasing activity of industry worldwide has led to a higher demand for green technologies for industrial water and wastewater treatment. This review covers the increasing interest in utilizing algae and seaweed-based adsorbents for heavy metals removal. As a low-cost biomass, algae and seaweed have promising reliability to be alternative adsorbent materials along with socioeconomical and environmental considerations. Other than that, some existing technologies for treating metal-contaminated water such as membrane filtration, coagulation and flocculation, biological and hybrid methods are also criticized to some extent. Furthermore, a comprehensive discussion of heavy metals' characteristics, sources, and toxicity effects is properly reviewed supporting 
the importance of heavy metal elimination from water bodies. Based on the current literature, a clear conclusion can be drawn that this type of adsorbent has excellent potential for metal removal. Therefore, the recommendation of future study focusing on the treatment of raw industrial wastewaters on the large-scale could be encouraged by exploring other novel species of algae and seaweed, modifying biomass preparation methods prior to the adsorption process, and assessing novel ways of achieving low-cost adsorbent regeneration.

Author Contributions: Conceptualization, S.M. and H.Z.; writing-original draft preparation, S.M.; writing-review and editing, H.Z., M.R.A. and S.M.; supervision, H.Z., M.R.A.; project administration, H.Z. and S.M.; funding acquisition, H.Z. All authors have read and agreed to the published version of the manuscript.

Funding: This research received no external funding.

Acknowledgments: The authors thank Curtin University and Universitas Muhammadiyah Palembang for the provided support. The authors also appreciate the anonymous reviewers and editors, whose constructive comments have greatly improved the quality of this paper.

Conflicts of Interest: The authors declare no conflict of interest.

\section{References}

1. Bhattacharjee, C.; Dutta, S.; Saxena, V.K. A review on biosorptive removal of dyes and heavy metals from wastewater using watermelon rind as biosorbent. Environ. Adv. 2020, 2, 100007. [CrossRef]

2. Mishra, S.; Cheng, L.; Maiti, A. The utilization of agro-biomass/byproducts for effective bio-removal of dyes from dyeing wastewater: A comprehensive review. J. Environ. Chem. Eng. 2021, 9, 104901. [CrossRef]

3. Martini, S.; Roni, K.A. The existing technology and the application of digital artificial intelligent in the wastewater treatment area: A review paper. In Journal of Physics: Conference Series; IOP Publishing: Bristol, UK, 2021; p. 012013.

4. Chakraborty, R.; Asthana, A.; Singh, A.K.; Jain, B.; Susan, A.B.H. Adsorption of heavy metal ions by various low-cost adsorbents: A review. Int. J. Environ. Anal. Chem. 2020, 102, 342-379. [CrossRef]

5. Kerur, S.S.; Bandekar, S.; Hanagadakar, M.S.; Nandi, S.S.; Ratnamala, G.M.; Hegde, P.G. Removal of hexavalent ChromiumIndustry treated water and Wastewater: A review. Mater. Today Proc. 2021, 42, 1112-1121. [CrossRef]

6. Qiu, B.; Tao, X.; Wang, H.; Li, W.; Ding, X.; Chu, H. Biochar as a low-cost adsorbent for aqueous heavy metal removal: A review. J. Anal. Appl. Pyrolysis 2021, 155, 105081. [CrossRef]

7. Bilal, M.; Ihsanullah, I.; Younas, M.; Ul Hassan Shah, M. Recent advances in applications of low-cost adsorbents for the removal of heavy metals from water: A critical review. Sep. Purif. Technol. 2021, 278, 119510. [CrossRef]

8. Tamjidi, S.; Esmaeili, H. Chemically modified $\mathrm{CaO} / \mathrm{Fe}_{3} \mathrm{O}_{4}$ nanocomposite by sodium dodecyl sulfate for $\mathrm{Cr}$ (III) removal from water. Chem. Eng. Technol. 2019, 42, 607-616. [CrossRef]

9. El Gheriany, I.A.; El Saqa, F.A.; Amer, A.A.E.R.; Hussein, M. Oil spill sorption capacity of raw and thermally modified orange peel waste. Alex. Eng. J. 2020, 59, 925-932. [CrossRef]

10. Afroze, S.; Sen, T.K. A review on heavy metal ions and dye adsorption from water by agricultural solid waste adsorbents. Water Air Soil Pollut. 2018, 229, 225. [CrossRef]

11. Foday, E.H., Jr.; Bo, B.; Xu, X. Removal of Toxic Heavy Metals from Contaminated Aqueous Solutions Using Seaweeds: A Review. Sustainability 2021, 13, 12311. [CrossRef]

12. Gümüş, N.E.; Aşıkkutlu, B.; Keskinkaya, H.B.; Akköz, C. Comparison of heavy metal absorption of some algae isolated from Altınapa Dam Lake (Konya). J. Anatol. Environ. Anim. Sci. 2021, 1, 50-56. [CrossRef]

13. Ahmed, S.F.; Mofijur, M.; Parisa, T.A.; Islam, N.; Kusumo, F.; Inayat, A.; Le, V.G.; Badruddin, I.A.; Khan, T.M.Y.; Ong, H.C. Progress and challenges of contaminate removal from wastewater using microalgae biomass. Chemosphere 2022, 286, 131656. [CrossRef] [PubMed]

14. He, J.; Chen, J.P. A comprehensive review on biosorption of heavy metals by algal biomass: Materials, performances, chemistry, and modeling simulation tools. Bioresour. Technol. 2014, 160, 67-78. [CrossRef] [PubMed]

15. Antuña-Nieto, C.; Rodríguez, E.; Lopez-Anton, M.A.; García, R.; Martínez-Tarazona, M.R. Noble metal-based sorbents: A way to avoid new waste after mercury removal. J. Hazard. Mater. 2020, 400, 123168. [CrossRef] [PubMed]

16. Di Natale, F.; Lancia, A.; Molino, A.; Di Natale, M.; Karatza, D.; Musmarra, D. Capture of mercury ions by natural and industrial materials. J. Hazard. Mater. 2006, 132, 220-225. [CrossRef]

17. Rae, I.B.; Gibb, S.W.; Lu, S. Biosorption of Hg from aqueous solutions by crab carapace. J. Hazard. Mater. 2009, 164, 1601-1604. [CrossRef]

18. Low, K.; Lee, C.; Liew, S. Sorption of cadmium and lead from aqueous solutions by spent grain. Process Biochem. 2000, 36, 59-64. [CrossRef]

19. Assi, M.A.; Hezmee, M.N.M.; Abd Wahid Haron, M.Y.M.; Sabri, M.A.R. The detrimental effects of lead on human and animal health. Vet. World 2016, 9, 660. [CrossRef] 
20. Mishra, P.; Patel, R. Removal of lead and zinc ions from water by low cost adsorbents. J. Hazard. Mater. 2009, 168, 319-325. [CrossRef]

21. Wang, Y.; Tsang, D.C. Effects of solution chemistry on arsenic(V) removal by low-cost adsorbents. J. Environ. Sci. 2013, 25, 2291-2298. [CrossRef]

22. Timalsina, H.; Mainali, B.; Angove, M.J.; Komai, T.; Paudel, S.R. Potential modification of groundwater arsenic removal filter commonly used in Nepal: A review. Groundw. Sustain. Dev. 2021, 12, 100549. [CrossRef]

23. Mondal, P.; Majumder, C.; Mohanty, B. Laboratory based approaches for arsenic remediation from contaminated water: Recent developments. J. Hazard. Mater. 2006, 137, 464-479. [CrossRef] [PubMed]

24. Tavares, D.S.; Lopes, C.B.; Coelho, J.P.; Sánchez, M.E.; Garcia, A.I.; Duarte, A.C.; Otero, M.; Pereira, E. Removal of arsenic from aqueous solutions by sorption onto sewage sludge-based sorbent. Water Air Soil Pollut. 2012, 223, 2311-2321. [CrossRef]

25. Tabelin, C.B.; Igarashi, T.; Villacorte-Tabelin, M.; Park, I.; Opiso, E.M.; Ito, M.; Hiroyoshi, N. Arsenic, selenium, boron, lead, cadmium, copper, and zinc in naturally contaminated rocks: A review of their sources, modes of enrichment, mechanisms of release, and mitigation strategies. Sci. Total Environ. 2018, 645, 1522-1553. [CrossRef] [PubMed]

26. Mi, F.-L.; Wu, S.-J.; Lin, F.-M. Adsorption of copper(II) ions by a chitosan-oxalate complex biosorbent. Int. J. Biol. Macromol. 2015 72, 136-144. [CrossRef] [PubMed]

27. Qi, F.; Lamb, D.; Naidu, R.; Bolan, N.S.; Yan, Y.; Ok, Y.S.; Rahman, M.M.; Choppala, G. Cadmium solubility and bioavailability in soils amended with acidic and neutral biochar. Sci. Total Environ. 2018, 610-611, 1457-1466. [CrossRef]

28. Ahmaruzzaman, M.; Gupta, V.K. Rice husk and its ash as low-cost adsorbents in water and wastewater treatment. Ind. Eng. Chem. Res. 2011, 50, 13589-13613. [CrossRef]

29. Kazakis, N.; Kantiranis, N.; Kalaitzidou, K.; Kaprara, E.; Mitrakas, M.; Frei, R.; Vargemezis, G.; Vogiatzis, D.; Zouboulis, A.; Filippidis, A. Environmentally available hexavalent chromium in soils and sediments impacted by dispersed fly ash in Sarigkiol basin (Northern Greece). Environ. Pollut. 2018, 235, 632-641. [CrossRef]

30. Es-sahbany, H.; Berradi, M.; Nkhili, S.; Hsissou, R.; Allaoui, M.; Loutfi, M.; Bassir, D.; Belfaquir, M.; El Youbi, M.S. Removal of heavy metals (nickel) contained in wastewater-models by the adsorption technique on natural clay. Mater. Today Proc. 2019, 13, 866-875. [CrossRef]

31. Hannachi, Y.; Shapovalov, N.A.; Hannachi, A. Adsorption of nickel from aqueous solution by the use of low-cost adsorbents. Korean J. Chem. Eng. 2010, 27, 152-158. [CrossRef]

32. Bibaj, E.; Lysigaki, K.; Nolan, J.; Seyedsalehi, M.; Deliyanni, E.; Mitropoulos, A.; Kyzas, G. Activated carbons from banana peels for the removal of nickel ions. Int. J. Environ. Sci. Technol. 2019, 16, 667-680. [CrossRef]

33. Hawari, A.; Rawajfih, Z.; Nsour, N. Equilibrium and thermodynamic analysis of zinc ions adsorption by olive oil mill solid residues. J. Hazard. Mater. 2009, 168, 1284-1289. [CrossRef]

34. Akpor, O.B.; Ohiobor, G.O.; Olaolu, D. Heavy metal pollutants in wastewater effluents: Sources, effects and remediation. Adv. Biosci. Bioeng. 2014, 2, 37-43. [CrossRef]

35. Cheremisinoff, N.P. Handbook of Water and Wastewater Treatment Technologies; Butterworth-Heinemann: Oxford, UK, 2001.

36. Agarwal, A.; Upadhyay, U.; Sreedhar, I.; Singh, S.A.; Patel, C.M. A review on valorization of biomass in heavy metal removal from wastewater. J. Water Process Eng. 2020, 38, 101602. [CrossRef]

37. Trellu, C.; Mousset, E.; Pechaud, Y.; Huguenot, D.; van Hullebusch, E.D.; Esposito, G.; Oturan, M.A. Removal of hydrophobic organic pollutants from soil washing/flushing solutions: A critical review. J. Hazard. Mater. 2016, 306, 149-174. [CrossRef]

38. Xu, H.; Yang, B.; Liu, Y.; Li, F.; Song, X.; Cao, X.; Sand, W. Evolution of microbial populations and impacts of microbial activity in the anaerobic-oxic-settling-anaerobic process for simultaneous sludge reduction and dyeing wastewater treatment. J. Clean. Prod. 2021, 282, 124403. [CrossRef]

39. Pang, Y.L.; Abdullah, A.Z. Current status of textile industry wastewater management and research progress in Malaysia: A review. Clean-Soil Air Water 2013, 41, 751-764. [CrossRef]

40. Mishra, S.; Maiti, A. Biological methodologies for treatment of textile wastewater. In Environmental Processes and Management; Springer: Berlin/Heidelberg, Germany, 2020; pp. 77-107.

41. Gómez-Ramírez, M.; Tenorio-Sánchez, S.A. Treatment of solid waste containing metals by biological methods. In Natural Resources Management and Biological Sciences; IntechOpen: London, UK, 2020.

42. Venegas, M.; Leiva, A.M.; Reyes-Contreras, C.; Neumann, P.; Piña, B.; Vidal, G. Presence and fate of micropollutants during anaerobic digestion of sewage and their implications for the circular economy: A short review. J. Environ. Chem. Eng. 2021, 9, 104931. [CrossRef]

43. Yang, C.; Xu, W.; Nan, Y.; Wang, Y.; Hu, Y.; Gao, C.; Chen, X. Fabrication and characterization of a high performance polyimide ultrafiltration membrane for dye removal. J. Coll. Interface Sci. 2020, 562, 589-597. [CrossRef]

44. Liu, X.; Jiang, B.; Yin, X.; Ma, H.; Hsiao, B.S. Highly permeable nanofibrous composite microfiltration membranes for removal of nanoparticles and heavy metal ions. Sep. Purif. Technol. 2020, 233, 115976. [CrossRef]

45. Saleh, T.A.; Gupta, V.K. Nanomaterial and Polymer Membranes: Synthesis, Characterization, and Applications; Elsevier: Amsterdam, The Netherlands, 2016.

46. Khan, I.A.; Lee, Y.S.; Kim, J.O. A comparison of variations in blocking mechanisms of membrane-fouling models for estimating flux during water treatment. Chemosphere 2020, 259, 127328. [CrossRef] [PubMed] 
47. Zhao, C.; Zhou, J.; Yan, Y.; Yang, L.; Xing, G.; Li, H.; Wu, P.; Wang, M.; Zheng, H. Application of coagulation/flocculation in oily wastewater treatment: A review. Sci. Total Environ. 2020, 765, 142795. [CrossRef] [PubMed]

48. Drinan, J.E.; Spellman, F. Water and Wastewater Treatment: A Guide for the Nonengineering Professional, 2nd ed.; CRC Press: Boca Raton, FL, USA, 2012.

49. Kurniawan, T.A.; Chan, G.Y.; Lo, W.-H.; Babel, S. Physico-chemical treatment techniques for wastewater laden with heavy metals. Chem. Eng. J. 2006, 118, 83-98. [CrossRef]

50. Aljuboury, D.a.d.A.; Shaik, F. Assessment of $\mathrm{TiO}_{2} / \mathrm{ZnO} / \mathrm{H}_{2} \mathrm{O}_{2}$ Photocatalyst to treat wastewater from oil refinery within visible light circumstances. S. Afr. J. Chem. Eng. 2021, 35, 69-77. [CrossRef]

51. Andreozzi, R.; Caprio, V.; Insola, A.; Marotta, R. Advanced oxidation processes (AOP) for water purification and recovery. Catal. Today 1999, 53, 51-59. [CrossRef]

52. Ochando-Pulido, J.M.; Victor-Ortega, M.D.; Hodaifa, G.; Martinez-Ferez, A. Physicochemical analysis and adequation of olive oil mill wastewater after advanced oxidation process for reclamation by pressure-driven membrane technology. Sci. Total Environ. 2015, 503-504, 113-121. [CrossRef]

53. Garrido-Cardenas, J.A.; Esteban-García, B.; Agüera, A.; Sánchez-Pérez, J.A.; Manzano-Agugliaro, F. Wastewater treatment by advanced oxidation process and their worldwide research trends. Int. J. Environ. Res. Public Health 2020, 17, 170. [CrossRef]

54. Martini, S.; Znad, H.T.; Ang, H.M. Photo-assisted fenton process for the treatment of canola oil effluent. In Chemeca 2014: Processing Excellence; Powering our Future, Engineers Australia: Barton, ACT, Australia, 2014; pp. 1519-1533.

55. Salleh, M.A.M.; Mahmoud, D.K.; Karim, W.A.W.A.; Idris, A. Cationic and anionic dye adsorption by agricultural solid wastes: A comprehensive review. Desalination 2011, 280,1-13. [CrossRef]

56. Barambu, N.U.; Bilad, M.R.; Bustam, M.A.; Kurnia, K.A.; Othman, M.H.D.; Nordin, N.A.H.M. Development of membrane material for oily wastewater treatment: A review. Ain Shams Eng. J. 2020, 12, 1361-1374. [CrossRef]

57. Martini, S.; Yuliwati, E. Membrane Development and Its Hybrid Application for Oily Wastewater Treatment: A Review. J. Appl. Membr. Sci. Technol. 2020, 25, 57-71.

58. Martini, S.; Ang, H.M. Hybrid $\mathrm{TiO}_{2} / \mathrm{UV} / \mathrm{PVDF}$ ultrafiltration membrane for raw canola oil wastewater treatment. Desalination Water Treat. 2019, 148, 51-59. [CrossRef]

59. Khalifa, O.; Banat, F.; Srinivasakannan, C.; AlMarzooqi, F.; Hasan, S.W. Ozonation-assisted electro-membrane hybrid reactor for oily wastewater treatment: A methodological approach and synergy effects. J. Clean. Prod. 2021, 289, 125764. [CrossRef]

60. Medhat, A.; El-Maghrabi, H.H.; Abdelghany, A.; Abdel Menem, N.M.; Raynaud, P.; Moustafa, Y.M.; Elsayed, M.A.; Nada, A.A. Efficiently activated carbons from corn cob for methylene blue adsorption. Appl. Surf. Sci. Adv. 2021, 3, 100037. [CrossRef]

61. Bilal, M.; Shah, J.A.; Ashfaq, T.; Gardazi, S.M.H.; Tahir, A.A.; Pervez, A.; Haroon, H.; Mahmood, Q. Waste biomass adsorbents for copper removal from industrial wastewater-A review. J. Hazard. Mater. 2013, 263, 322-333. [CrossRef] [PubMed]

62. Li, Y.; Liu, J.; Yuan, Q.; Tang, H.; Yu, F.; Lv, X. A green adsorbent derived from banana peel for highly effective removal of heavy metal ions from water. RSC Adv. 2016, 6, 45041-45048. [CrossRef]

63. Huang, K.; Xiu, Y.; Zhu, H. Removal of heavy metal ions from aqueous solution by chemically modified mangosteen pericarp. Desalination Water Treat. 2014, 52, 7108-7116. [CrossRef]

64. Rosales, E.; Meijide, J.; Tavares, T.; Pazos, M.; Sanromán, M. Grapefruit peelings as a promising biosorbent for the removal of leather dyes and hexavalent chromium. Process Saf. Environ. Prot. 2016, 101, 61-71. [CrossRef]

65. Al Ketife, A.M.D.; Almomani, F.; Znad, H. Sustainable removal of copper from wastewater using chemically treated biosorbent: Characterization, mechanism and process kinetics. Env. Technol. Innovation. 2021, 23, 101555. [CrossRef]

66. Veglio, F.; Beolchini, F. Removal of metals by biosorption: A review. Hydrometallurgy 1997, 44, 301-316. [CrossRef]

67. Vijayaraghavan, K.; Balasubramanian, R. Is biosorption suitable for decontamination of metal-bearing wastewaters? A critical review on the state-of-the-art of biosorption processes and future directions. J. Environ. Manag. 2015, 160, 283-296. [CrossRef]

68. Martini, S.; Afroze, S. Current development of sorbents derived from plant and animal waste as green solution for treating polluted aqueous media. J. Teknol. 2021, 83, 175-191. [CrossRef]

69. Lingamdinne, L.P.; Vemula, K.R.; Chang, Y.-Y.; Yang, J.-K.; Karri, R.R.; Koduru, J.R. Process optimization and modeling of lead removal using iron oxide nanocomposites generated from bio-waste mass. Chemosphere 2020, 243, 125257. [CrossRef] [PubMed]

70. Wahi, R.; Abdullah, L.C.; Mobarekeh, M.N.; Ngaini, Z.; Yaw, T.C.S. Utilization of esterified sago bark fibre waste for removal of oil from palm oil mill effluent. J. Environ. Chem. Eng. 2017, 5, 170-177. [CrossRef]

71. Martini, S.; Afroze, S.; Roni, K.A. Modified eucalyptus bark as a sorbent for simultaneous removal of COD, oil, and Cr (III) from industrial wastewater. Alex. Eng. J. 2020, 59, 1637-1648. [CrossRef]

72. Foroutan, R.; Esmaeili, H.; Abbasi, M.; Rezakazemi, M.; Mesbah, M. Adsorption behavior of Cu (II) and Co (II) using chemically modified marine algae. Environ. Technol. 2018, 39, 2792-2800. [CrossRef]

73. Abedi, S.; Zavvar Mousavi, H.; Asghari, A. Investigation of heavy metal ions adsorption by magnetically modified aloe vera leaves ash based on equilibrium, kinetic and thermodynamic studies. Desalination Water Treat. 2016, 57, 13747-13759. [CrossRef]

74. Adeniyi, A.G.; Ighalo, J.O. Biosorption of pollutants by plant leaves: An empirical review. J. Environ. Chem. Eng. 2019, 7, 10310. [CrossRef]

75. Ezeonuegbu, B.A.; Machido, D.A.; Whong, C.M.Z.; Japhet, W.S.; Alexiou, A.; Elazab, S.T.; Qusty, N.; Yaro, C.A.; Batiha, G.E.-S. Agricultural waste of sugarcane bagasse as efficient adsorbent for lead and nickel removal from untreated wastewater: Biosorption, equilibrium isotherms, kinetics and desorption studies. Biotechnol. Rep. 2021, 30, e00614. [CrossRef] 
76. Kumar, P.; Chauhan, M.S. Adsorption of chromium (VI) from the synthetic aqueous solution using chemically modified dried water hyacinth roots. J. Environ. Chem. Eng. 2019, 7, 103218. [CrossRef]

77. Ma, Y.; Liu, W.-J.; Zhang, N.M.; Li, Y.-S.; Jiang, H.; Sheng, G.-P. Polyethylenimine modified biochar adsorbent for hexavalent chromium removal from the aqueous solution. Bioresour. Technol. 2014, 169, 403-408. [CrossRef]

78. Volesky, B. Biosorption and me. Water Res. 2007, 41, 4017-4029. [CrossRef] [PubMed]

79. Ahsan, M.A.; Katla, S.K.; Islam, M.T.; Hernandez-Viezcas, J.A.; Martinez, L.M.; Díaz-Moreno, C.A.; Lopez, J.; Singamaneni, S.R.; Banuelos, J.; Gardea-Torresdey, J. Adsorptive removal of methylene blue, tetracycline and $\mathrm{Cr}$ (VI) from water using sulfonated tea waste. Environ. Technol. Innov. 2018, 11, 23-40. [CrossRef]

80. Dawood, S.; Sen, T.; Phan, C. Synthesis and Characterisation of Novel-Activated carbon from waste biomass pine cone and its application in the removal of congo red dye from aqueous solution by adsorption. Water Air Soil Pollut. 2014, 225, 1-16. [CrossRef]

81. Dubinin, M.; Radushkevich, L. Evaluation of Microporous Material with a New Isotherm. Proc. USSR Acad. Sci. 1966, 55, 331-347.

82. Ayawei, N.; Ebelegi, A.N.; Wankasi, D. Modelling and interpretation of adsorption isotherms. J. Chem. 2017, $2017,3039817$. [CrossRef]

83. Al Haddabi, M.; Vuthaluru, H.; Znad, H.; Ahmed, M. Attapulgite as potential adsorbent for dissolved organic carbon from oily water. CLEAN Soil Air Water 2015, 43, 1522-1530. [CrossRef]

84. Nandi, B.K.; Goswami, A.; Purkait, M.K. Removal of cationic dyes from aqueous solutions by kaolin: Kinetic and equilibrium studies. Appl. Clay Sci. 2009, 42, 583-590. [CrossRef]

85. Sen, T.K.; Sarzali, M.V. Removal of cadmium metal ion $\left(\mathrm{Cd}^{2+}\right)$ from its aqueous solution by aluminium oxide $\left(\mathrm{Al}_{2} \mathrm{O}_{3}\right)$ : $\mathrm{A} \mathrm{kinetic}$ and equilibrium study. Chem. Eng. J. 2008, 142, 256-262. [CrossRef]

86. El Shahawy, A.; Heikal, G. Organic pollutants removal from oily wastewater using clean technology economically, friendly biosorbent (Phragmites australis). Ecol. Eng. 2018, 122, 207-218. [CrossRef]

87. Cheng, S.Y.; Show, P.-L.; Lau, B.F.; Chang, J.-S.; Ling, T.C. New Prospects for Modified Algae in Heavy Metal Adsorption. Trends Biotechnol. 2019, 37, 1255-1268. [CrossRef]

88. Abdullah Al-Dhabi, N.; Arasu, M.V. Biosorption of hazardous waste from the municipal wastewater by marine algal biomass. Environ. Res. 2022, 204, 112115. [CrossRef] [PubMed]

89. El-Naggar, N.E.-A.; Hamouda, R.A.; Mousa, I.E.; Abdel-Hamid, M.S.; Rabei, N.H. Biosorption optimization, characterization, immobilization and application of Gelidium amansii biomass for complete $\mathrm{Pb}^{2+}$ removal from aqueous solutions. Sci. Rep. 2018, 8, 13456. [CrossRef] [PubMed]

90. Yalçın, S.; Özyürek, M. Biosorption potential of two brown seaweeds in the removal of chromium. Water Sci. Technol. 2018, 78, 2564-2576. [CrossRef] [PubMed]

91. Husien, S.; Labena, A.; El-Belely, E.; Mahmoud, H.M.; Hamouda, A.S. Adsorption studies of hexavalent chromium [Cr (VI)] on micro-scale biomass of Sargassum dentifolium, Seaweed. J. Environ. Chem. Eng. 2019, 7, 103444. [CrossRef]

92. Moino, B.P.; Costa, C.S.; da Silva, M.G.; Vieira, M.G. Removal of nickel ions on residue of alginate extraction from Sargassum filipendula seaweed in packed bed. Can. J. Chem Eng. 2017, 95, 2120-2128. [CrossRef]

93. Zhou, H.; Zhao, X.; Kumar, K.; Kunetz, T.; Zhang, Y.; Gross, M.; Wen, Z. Removing high concentration of nickel (II) ions from synthetic wastewater by an indigenous microalgae consortium with a Revolving Algal Biofilm (RAB) system. Algal Res. 2021, 59, 102464. [CrossRef]

94. Raju, C.A.I.; Anitha, J.; Mahalakshmi Kalyani, R.; Satyanandam, K.; Jagadeesh, P. Sorption of cobalt using marine macro seaweed graciliariacorticatared algae powder. Mater. Today Proc. 2021, 44, 1816-1827. [CrossRef]

95. Vafajoo, L.; Cheraghi, R.; Dabbagh, R.; McKay, G. Removal of cobalt (II) ions from aqueous solutions utilizing the pre-treated 2-Hypnea Valentiae algae: Equilibrium, thermodynamic, and dynamic studies. Chem. Eng. J. 2018, 331, 39-47. [CrossRef]

96. Nishikawa, E.; da Silva, M.G.C.; Vieira, M.G.A. Cadmium biosorption by alginate extraction waste and process overview in Life Cycle Assessment context. J. Clean. Prod. 2018, 178, 166-175. [CrossRef]

97. Vieira, B.R.; Pintor, A.M.; Boaventura, R.A.; Botelho, C.M.; Santos, S.C. Arsenic removal from water using iron-coated seaweeds. J. Environ. Manag. 2017, 192, 224-233. [CrossRef]

98. Fabre, E.; Dias, M.; Costa, M.; Henriques, B.; Vale, C.; Lopes, C.B.; Pinheiro-Torres, J.; Silva, C.M.; Pereira, E. Negligible effect of potentially toxic elements and rare earth elements on mercury removal from contaminated waters by green, brown and red living marine macroalgae. Sci. Total Environ. 2020, 724, 138133. [CrossRef] [PubMed]

99. Senthilkumar, R.; Prasad, D.R.; Govindarajan, L.; Saravanakumar, K.; Prasad, B.N. Green alga-mediated treatment process for removal of zinc from synthetic solution and industrial effluent. Environ. Technol. 2017, 40, 1262-1270. [CrossRef] [PubMed]

100. Jayakumar, V.; Govindaradjane, S.; Rajasimman, M. Efficient adsorptive removal of Zinc by green marine macro alga Caulerpa scalpelliformis-Characterization, Optimization, Modeling, Isotherm, Kinetic, Thermodynamic, Desorption and Regeneration Studies. Surf. Interfaces 2021, 22, 100798. [CrossRef]

101. Jayakumar, V.; Govindaradjane, S.; Rajamohan, N.; Rajasimman, M. Biosorption potential of brown algae, Sargassum polycystum, for the removal of toxic metals, cadmium and zinc. Environ. Sci. Pollut. Res. 2021, 1-14. [CrossRef]

102. Costa, C.S.D.; Bertagnolli, C.; Boos, A.; da Silva, M.G.C.; Vieira, M.G.A. Application of a dealginated seaweed derivative for the simultaneous metal ions removal from real and synthetic effluents. J. Water Process Eng. 2020, 37, 101546. [CrossRef]

103. El-Sheekh, M.; El-Sabagh, S.; Abou Elsoud, G.; Elbeltagy, A. Efficacy of immobilized biomass of the seaweeds Ulva lactuca and Ulva fasciata for cadmium biosorption. Iran. J. Sci. Technol. Trans. A Sci. 2020, 44, 37-49. [CrossRef] 
104. Henriques, B.; Rocha, L.S.; Lopes, C.B.; Figueira, P.; Monteiro, R.J.; Duarte, A.D.C.; Pardal, M.; Pereira, E. Study on bioaccumulation and biosorption of mercury by living marine macroalgae: Prospecting for a new remediation biotechnology applied to saline waters. Chem. Eng. J. 2015, 281, 759-770. [CrossRef]

105. Lata, S.; Singh, P.; Samadder, S. Regeneration of adsorbents and recovery of heavy metals: A review. Int. J. Environ. Sci. Technol. 2015, 12, 1461-1478. [CrossRef] 